Research Report No. 10/2009

\title{
Judicial Independence as a Public Policy Instrument
}

Adam M. Dodek

Follow this and additional works at: http:/ / digitalcommons.osgoode.yorku.ca/clpe

\section{Recommended Citation}

Dodek, Adam M., "Judicial Independence as a Public Policy Instrument" (2009). Comparative Research in Law \& Political Economy. Research Paper No. 10/2009.

http://digitalcommons.osgoode.yorku.ca/clpe/125 


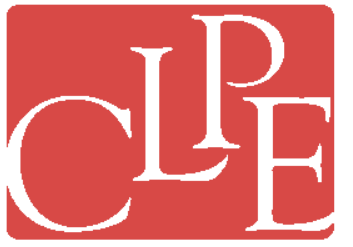

\section{Comparative Research in Law \& Political Economy}

\section{Adam M. Dodek}

\section{Judicial Independence as a Public Policy Instrument}

EDITORS: Peer Zumbansen (Osgoode Hall Law School, Toronto, Director, Comparative Research in Law and Political Economy, York University), John W. Cioffi (University of California at Riverside), Nassim Nasser (Osgoode Hall Law School, Toronto, Production Editor) 

CLPE Research Paper 10/2009

Vol. 05 No. 02 (2009)

\title{
Adam M. Dodek
}

\section{Judicial Independence as a Public Policy Instrument}

\begin{abstract}
The participation of judges in commissions of inquiry has been an important part of the public policy process in Canada and elsewhere. However, the use of judges for these and other extra-judicial functions is not wholly positive and the other side of the balance must be considered as well. This paper chronicles the dramatic rise of the use of judges by governments for such policy functions, arguing that it has resulted in a "judicialization of politics" of a different sort from the standard conception of that term. The current political culture of independence and accountability has made judicial independence a highly valued political commodity that is frequently in demand by government officials. This paper argues that what public policy makers are seeking is not simply the expertise of judges but also the political capital of judicial independence which has become an increasingly valued political good in Canadian society (and likely in others as well). This paper analyzes and evaluates this trend from the perspective of judicial independence and argues that the unreflective reliance on judges for various extra-judicial functions has the potential to undermine the bedrock principle of judicial independence if it is not better managed by the judiciary in concert with the executive. This paper analyzes two cautionary tales from the use of judicial independence for public policy purposes: the Gomery Inquiry and the controversy over the Chief Justice's involvement in the award of the Order of Canada to abortion activist Dr. Henry Morgentaler. Finally, this paper ends with the argument that taking judicial independence seriously necessitates that judges develop a framework for the consideration of extra-judicial functions and begin to exercise greater discretion in refusing to take on executive functions at times, lest the political currency of judicial independence become devalued over time.
\end{abstract}

Keywords: Judicial Independence, Judges, Canada, Public Policy, Extra-Judicial, Abortion, Public Inquiries, Commissions of Inquiry, Executive, Judiciary.

JEL classification: K19, K40, L38.

Adam M. Dodek, Associate Professor Faculty of Law - Common Law Section University of Ottawa, Fauteux Hall 57 Louis Pasteur Ottawa, ON K1N 6N5. Email: Adam.Dodek@uottawa.ca 


\title{
JUDICIAL INDEPENDENCE AS A PUBLIC POLICY INSTRUMENT
}

\author{
Adam M. Dodek ${ }^{*}$
}

\section{INTRODUCTION}

In the fall of 2007, then Pakistani President Pervez Musharraf declared a state of emergency, suspended the Constitution and summarily dismissed the Chief Justice and other members of the High Court. ${ }^{1}$ Images of middle-class lawyers in court attire clashing with police were broadcast around the world. In the campaign for parliamentary elections held in February 2008, the two leading opposition parties pledged to restore the independence of the judiciary. For the opposition, hitching their political wagon to the independence of judiciary was a highly successful political strategy which contributed to their overwhelming victory. However, after they formed the government, the two parties quickly began to bicker over the details of restoring the deposed judges, leading to a political stalemate.

The Pakistani experience is instructive because of the transparency with which judicial independence was used for political purposes. In less overt instances, governments in common law countries have long turned to judges to address some of the most vexing and controversial public policy issues of the day. Commissions of inquiry are the most obvious example. In the United States, Chief Justice Earl Warren headed the Commission which bore his name investigating the assassination of President John F. Kennedy. In South Africa, President F.W. de Klerk and ANC leader Nelson Mandela tapped Justice Richard Goldstone ${ }^{2}$ to head an inquiry into allegations of state-sponsored violence that threatened to destabilize that country's democratic transition. In Israel, judges have headed commissions inquiring into intelligence failures of the Yom Kippur War, the massacres at the Sabra and Shatilla refugee camps in Lebanon in 1982 and most recently into Israel's prosecution of the war against Hezbollah in Lebanon in the summer of 2006. Public inquiries have a strong pedigree in the United Kingdom as well.

\footnotetext{
* Faculty of Law, University of Ottawa. Between 2003 and 2006, the author served successively as Senior Policy Advisor, Director of Policy and then Chief of Staff to the Attorney General of Ontario. The author had the opportunity to reflect upon various issues including this one and the author expresses his gratitude to the members of the Policy Branch of the Ontario Ministry of the Attorney General generally for their dedication and professionalism in the development of public policy in Ontario and specifically for their hospitality in inviting the author to present a paper in July 2007 that formed the basis for this paper. Thanks also to Jamie Cameron, Lynda Collins, Jameson Doig, Mark Leach, Henry Molot, Ed Ratushny, Lorne Sossin and several members of the judiciary for reading earlier drafts of this paper and providing helpful comments. Special thanks to Professor Greg Taylor of Monash University for educating me about the controversial role of judges serving on commissions of inquiry in Australia. Email: Adam.Dodek@uottawa.ca

${ }^{1}$ See the chapters by Justice Robert Sharpe and Janice Gross Stein in this volume.

${ }^{2}$ Justice Goldstone has authored the Foreword to this volume.
} 
Canada inherited this penchant for public inquiries ${ }^{3}$ and their popularity stretches back beyond Canada's founding in $1867 .^{4}$ In recent years, however, public inquiries have become much more prevalent at both the federal and provincial levels with names like Arar, Gomery, Ipperwash, Air India, Tasers and the Truth and Reconciliation Commission (TRC) entering the Canadian political lexicon. Moreover, what is particularly striking in Canada is the vast expansion of the use of judges by governments for many "independent reviews" and other functions that may mix adjudicative, legislative and executive functions. Examples include the use of judges to head commissions that set electoral boundaries, targeted policy reviews and the appointment of sitting or retired judges as members or chairs of tribunals and officers of the legislature.

Much has been written about commissions of inquiry and their benefits and pitfalls in the public policy process. ${ }^{5}$ There is no question that the participation of judges in commissions of inquiry has been an important part of the public policy process in Canada. ${ }^{6}$ However, the use of judges for these and other extra-judicial functions is not wholly positive and the other side of the balance must be considered as well. This paper thus approaches this issue in a decidedly different manner that is at once more expansive and more narrowly focused. This chapter chronicles the dramatic rise of the use of judges by governments for such policy functions, arguing that it has resulted in a "judicialization of politics" of a different sort from the standard

\footnotetext{
${ }^{3}$ Public inquiries are variously referred to as commissions of inquiry or sometimes by the older term "royal commissions". In this paper, I use the terms public inquiries and commissions of inquiry interchangeably.

${ }^{4}$ See Thomas J. Lockwood, “A History of Royal Commissions” (1967) 5 Osgoode Hall L.J. 172; Watson Sellar, “A Century of Commissions of Inquiry" (1947) 24 Can. Bar Rev. 1; Canada, Library and Archives Canada, "Index to Federal Royal Commissions", online: http://www.collectionscanada.gc.ca/7/6/index-e.html (noting that there have been over 200 federal commissions of inquiry since Confederation in 1867).
}

${ }^{5}$ See e.g. Dennis R. O’Connor \& Freya Kristjanson, "Some Observations on Public Inquiries" (Paper presented at the Canadian Institute for the Administration of Justice's Annual Conference, Halifax, Nova Scotia, 10 October 2007), online: http://www.ontariocourts.on.ca/coa/en/ps/speeches/publicinquiries.htm (Alternate title: "Why Public Inquiries Work"); Justice John H. Gomery, "The Pros and Cons of Commissions of Inquiry” (2006) 51 McGill L.J. 783; Allan Manson \& David Mullan, eds., Commissions of Inquiry: Praise or Reappraise? (Toronto: Irwin Law, 2003); Nicholas d'Ombrain, "Public Inquiries in Canada" (1997) 40:1 Canadian Public Administration 86; A. Paul Pross, Innis Christie \& John A. Yogis, eds., Commissions of Inquiry (Toronto: Carswell, 1990); Gordon F. Henderson, "Abuse of Power by Royal Commissions" in Law Society of Upper Canada, Special Lectures (Toronto: Law Society of Upper Canada, 1979); Canada, Law Reform Commission, Report 13: Advisory and Investigatory Commissions (Ottawa: Supply and Services Canada, 1979); John C. Courtney, "In Defence of Royal Commissions" (Summer 1969) 12:2 Canadian Public Administration 204; J.E. Hodgetts, "Should Canada be De-Commissioned? A Commoner's View of Royal Commissions" (Winter 1964) 70:4 Queen's Quarterly 483.

6 Starr v. Houlden, [1990] 1 S.C.R. 1366 at 1410-11 (noting functions of public inquiries include enabling government to secure information as a basis for developing or implementing policy, educating the public or legislative branch, investigating the administration of government and permitting the public voicing of grievances); and ibid. at 1413 (per L'Heureux-Dubé J., dissenting, but not on this point ("neither my colleague nor any of the parties dispute the fact that commissions of inquiry have played a useful and necessary role in Canada"). 
conception of that term. The current political culture of independence and accountability has made judicial independence a highly valued political commodity that is frequently in demand by government officials. This chapter will argue that what public policy makers are seeking is not simply the expertise of judges but also the political capital of judicial independence which has become an increasingly valued political good in Canadian society (and likely in others as well).

In Canada we increasingly value independence from political decision making. ${ }^{7}$ This paper analyzes and evaluates this trend from the perspective of judicial independence. While I acknowledge that the use of judges for public policy purposes certainly has distinct benefits that have been well chronicled by others, my thesis is that this phenomenon also has the potential to undermine the bedrock principle of judicial independence if it is not better managed by the judiciary in concert with the executive. I begin therefore by examining the nature and purpose of judicial independence. I then describe the judicialization of politics noted above before analyzing two cautionary tales from the use of judicial independence for public policy purposes: the Gomery Inquiry and the controversy over the Chief Justice's involvement in the award of the Order of Canada to abortion activist Dr. Henry Morgentaler. Finally, this paper ends with the argument that taking judicial independence seriously necessitates that judges develop a framework for the consideration of extra-judicial functions and begin to exercise greater discretion in refusing to take on executive functions at times, lest the political currency of judicial independence become devalued over time.

\section{The NATURE AND PURPOSE OF JUdiCiAL INDEPENDENCE}

\section{A. THE InSTRUMENTAL CHARACTER OF JUdiCIAL INDEPENDENCE}

Judicial independence is a highly valued constitutional norm around the world. ${ }^{8}$ In Canada, it has been elevated to the status of an unwritten constitutional principle ${ }^{9}$ that has equal

\footnotetext{
${ }^{7}$ While it is beyond the scope of this paper, it is my assertion that governments' penchant of relying on outside "independent" experts such as judges has degraded both the capabilities and the legitimacy of the legislative and executive branches of government.
}

\footnotetext{
${ }^{8}$ See e.g. Universal Declaration of Human Rights (1948), art. 10 ("Everyone is entitled in full equality to a fair and public hearing by an independent and impartial tribunal, in the determination of his rights and obligations and of any criminal charge against him."); International Covenant on Civil and Political Rights, art. 14 ("All persons shall be equal before the courts and tribunals. In the determination of any criminal charge against him, or of his rights and obligations in a suit at law, everyone shall be entitled to a fair and public hearing by a competent, independent and impartial tribunal established by law."); Universal Declaration on the Independence of Justice (adopted by the First World Conference on the Independence of Justice, Montreal, June 1983) in Shimon Shetreet \& Jules Deschênes, eds., Judicial Independence: The Contemporary Debate (Dordrecht/Boston/Lancaster: Martinus Nijhoff Publishers, 1985) 447; United Nations. Implementation Of The Basic Principles On The Independence Of The Judiciary (adopted at the Eighth Congress On The Prevention Of Crime And Treatment Of Offenders. Havana, Cuba: 27
} 
if not stronger force than some of the textual provisions of Canada's Constitution. ${ }^{10}$ However, as Peter Russell explains in his contribution to this book, there has been a lack of agreement about what judicial independence encompasses. ${ }^{11}$ Russell's theoretical framework attempts to isolate and describe the elusive "it" that is judicial independence. In this chapter, I focus largely on judicial statements in order to set out the nature and purpose of judicial independence against which I evaluate its use as a policy good outside of the adjudication process in the sections that follow.

In Canada and around the world it is widely acknowledged that judicial independence is not an end in itself. Judicial independence, it is claimed, serves various other social and political objectives. $^{12}$ As Chief Justice Lamer asserted in the Provincial Judges Reference, "judicial independence ... is not an end it itself...[it] is valued because it serves important societal goals - it is a means to secure those goals."13 As Peter Russell has argued, "[t]hose who believe that some measure of judicial independence is desirable must hold this belief, because judicial independence is thought to serve some important objective, to contribute to some desirable state

August - 7 September, 1990 (A/Conf.144/190) and Corrigendum; United Nations,.Guidelines on the Independence of the Judiciary (adopted at the Seventh Congress on the Prevention of Crime and Treatment of Offenders, Milan, Italy: 26 August - 6 September 1985) (A/Conf.121/9) and Corrigendum; International Bar Association. Minimum Standards of Judicial Independence, 2006. On the value placed on judicial independence around the world see the contributions in this volume by Jameson Doig (United States), Penelope Andrews (South Africa), Graham Gee (United Kingdom), Justice Robert Sharpe (Pakistan), Amnon Reichman (Israel), Fabien Gélinas (international system) as well as the Foreword of Justice Richard Goldstone.

9 See Reference re Remuneration of Judges of the Provincial Court of Prince Edward Island; Reference re Independence and Impartiality of Judges of the Provincial Court of Prince Edward Island; R. v. Campbell; R. v. Ekmecic; R. v. Wickman; Manitoba Provincial Judges Assn. v. Manitoba (Minister of Justice), [1997] 3 S.C.R. 3 [Provincial Judges Reference].

${ }^{10}$ See the chapters of Peter Hogg and Amnon Reichman in this collection.

${ }^{11}$ See the contribution of Peter Russell in this collection. See also Linda Greenhouse, "Independence: why \& from what?" (Fall 2008) 137:4 Daedelus 5 at 5 ("'Judicial independence' is a concept easier to salute reflexively than to grasp fully.").

${ }^{12}$ See e.g. Judith Resnik, "Interdependent federal judiciaries: puzzling about why \& how to value the independence of which judges" (Fall 2008) 137:4 Daedelus 28 at 47 ("[j]udicial independence is an instrumental value"); Vicki C. Jackson, "Packages of judicial independence: implications for reform proposals on the selection \& tenure of Article III judges" (Fall 2008) 137:4 Daedelus 48 at 48 ("[j]udicial independence is necessary to assure the rule of law and protection of rights"); Charles Gardner Geyh, "Methods of judicial selection \& their impact on judicial independence" (Fall 2008) 137:4 Daedelus 86 at 86 ("Within the legal community judicial independence is understood, not as an intrinsic good or an end it itself, but as a means to achieve other ends."); Stephen B. Burbank \& Barry Friedman, "Reconsidering Judicial Independence" in Stephen B. Burbank \& Barry Friedman, eds., Judicial Independence at the Crossroads: An Interdisciplinary Approach (Thousand Oaks, CA: Sage Publications, 2002) 9 at 10 ("judicial independence is a means to an end (or, more probably, to more than one end") (emphasis in original). See also Peter H. Russell, "Toward a General Theory of Judicial Independence” in Peter H. Russell \& David M. O'Brien, eds., Judicial Independence in the Age of Democracy: Critical Perspectives from around the World (Charlottesville \& London: University of Virginia Press, 2001) 1 at 3.

13 Provincial Judges Reference, supra note 13 at para. 9. See also the Rt. Hon. Beverly McLachlin "Judicial Accountability" (2008) 1 Journal of Parliamentary and Political Law 293 at 298. 
of affairs." ${ }^{\prime 4}$ Judicial independence is thus a second order constitutional and political value by which I mean that its existence and vitality serves other first order values.

This instrumental view of judicial independence predominates in the literature ${ }^{15}$ and the jurisprudence although it is often lost in the heated rhetoric that arises when there are purported threats to judicial independence. Frequently in such cases, defenders against such perceived incursions fail to articulate the nature of the threat to judicial independence let alone how the threat undermines the relevant first order values that judicial independence is intended to protect. ${ }^{16}$ Judicial independence is regularly invoked as a shield against changes to judicial structure or benefits. However, such invocations of the shibboleth of judicial independence often overlook or ignore the idea that judicial independence is not an end it itself and certainly its purpose is not to protect judicial privileges. ${ }^{17}$ To better understand the nature and purpose of judicial independence it is necessary to hone in on the arguments for it.

\footnotetext{
${ }^{14}$ Peter H. Russell, "Toward a General Theory of Judicial Independence" in Peter H. Russell \& David M. O’Brien, eds., Judicial Independence in the Age of Democracy: Critical Perspectives from around the World (Charlottesville \& London: University of Virginia Press, 2001) 1 at 3.

${ }^{15}$ See e.g. Stephen B. Burbank \& Barry Friedman, "Reconsidering Judicial Independence" in Stephen B. Burbank \& Barry Friedman, eds., Judicial Independence at the Crossroads: An Interdisciplinary Approach (Thousand Oaks, CA: Sage Publications, 2002) 9 at 10-11; John Ferejohn, "Independent Judges, Dependent Judiciary, "Explaining Judicial Independence) (1999) 72 S. Cal. L. Rev. 353. Russell, "Towards a General Theory of Judicial Independence", ibid. at 2. In this volume see e.g. the contributions of Sonia Lawrence ("judicial independence is not a 'goal in itself,' but rather a means to impartiality and legitimacy, so that links between diversity and legitimacy and impartiality might not explicitly mention judicial independence despite a clear connection.”) (manuscript at 2); Rosemary Cairns Way ("The [Social Context Education Project] aimed to engaged that conceptualization directly by challenging participants to understand independence purposively as an essential means of protecting and fostering the core obligation of impartiality") (manuscript at 24), Patricia Hughes ("It is trite to say, but always worth remembering, that judicial independence is not an end in itself; rather, it is crucial to the rule of law and the ability of judges to be impartial.") (manuscript at 7).

${ }^{16}$ For example, in 2007 the Canadian Judicial Council and the bar vigorously opposed plans by the federal Minister of Justice to change the composition of the judicial advisory committees that vet candidates for federal judicial appointments but failed to convincingly articulate how such changes could threaten any of the values that the independence of the judiciary is intended to protect. See Tonda MacCharles, "Tories imperil neutral courts: Judges; Plans for advisory committees risk politicizing system, council argues" The Toronto Star (21 February 2007); Helen Burnett, "Independent judiciary put in peril" The Law Times (26 February 2007) (citing a Canadian Judicial Council letter openly criticizing proposed changes to the committees that advise on federal judicial appointments); Canadian Judicial Council, Press Release: Judicial Appointments: Perspective from the Canadian Judicial Council" (2 February 2007), online: http://www.cjc-ccm.gc.ca/english/news_en.asp?selMenu=news_2007_0220_en.asp. The arguments that such changes "imperiled" the independence of the judiciary were flimsy and empirical evidence to support such claims is rather weak.

${ }^{17}$ See Provincial Court Judges Reference, supra note 17 at para. 9 and Mackin v. New Brunswick (Minister of Finance); Rice v. New Brunswick, [2002] 1 S.C.R. 405, 2002 SCC 13 at para. 28 [Mackin].
} 


\section{B. INDEPENDENCE AND IMPARTIALITY INTERTWINED}

Most arguments for judicial independence are based on the critical connection between it and judicial impartiality. The customary case for judicial independence is composed of several interconnected strands. First, judicial independence is required to ensure judicial impartiality. Second, this impartiality in turn promotes public confidence in the impartial adjudication of disputes which secures the legitimacy of the legal system. Finally, such confidence and legitimacy upholds the Rule of Law, although at times it is asserted that judicial independence itself directly serves these functions. ${ }^{18}$ Let me attempt to unpack this by explaining the nexus and the distinction between judicial independence and judicial impartiality. The two concepts are closely linked and are often asserted in tandem: "[i]ndependent and impartial adjudication is essential to a free and democratic society." $"$ However, the twin ideas of independence and impartiality are distinct.

In Valente (1985), Justice Le Dain distinguished between the two concepts. He explained that "impartiality refers to a state of mind or attitude of the tribunal in relations to the issues and the parties in a particular case." 20 Independence, on the other hand, refers to the "status or relationship to others, particularly to the executive branch of government, that rests on objective conditions or guarantees. ${ }^{.21}$ It is asserted that independence is necessary in order to promote and protect impartiality. As Chief Justice Lamer explained in Lippé (1991), "[j]udicial independence is critical to the public's perception of impartiality. Independence is the cornerstone, a necessary prerequisite, for judicial impartiality." 22 Along similar lines, the Canadian Judicial Council has explained that "[j]udicial independence is not the private right of judges but the foundation of judicial impartiality and a constitutional right of all Canadians. Independence of the judiciary refers to the necessary individual and collective or institutional independence required for impartial decisions and decision making. ${ }^{23}$ Judicial independence is derivative of impartiality and a protective shield to ensure it.

Within each instrumental thread of judicial independence we can see how the concept is tied to the adjudication of disputes, the defining characteristic of the judicial function. Simply

\footnotetext{
${ }^{18}$ See e.g. Mackeigan v. Hickman, [1989] 2 S.C.R. 796 at para. 58.

${ }^{19}$ Martin L. Friedland, A Place Apart: Judicial Independence and Accountability in Canada (Ottawa: Canadian Judicial Council, 1995) 1. See also Canadian Judicial Council, Ethical Principles for Judges (Ottawa: Canadian Judicial Council, 1998) 7 (“An independent judiciary is indispensable to impartial justice under law.").

${ }^{20}$ R. v. Valente, [1985] 2 S.C.R. 673 at 685.

${ }^{21}$ Ibid. In Mackeigan, supra note 18 at para. 56, McLachlin J. (as she then was) explained that judicial impartiality involved a state of mind whereas judicial independence concerned the relationship between judges and others, particularly those in government.

${ }^{22}$ R. v. Lippé, [1991] 2 S.C.R. 114 at para. 48.

${ }^{23}$ Canadian Judicial Council, Ethical Principles for Judges (Ottawa: Canadian Judicial Council, 1998) 8.
} 
put, judges interpret and apply the law to specific situations; they adjudicate; they decide disputes. ${ }^{24}$ This is an obvious but important point and other functions that judges perform are subsidiary to this core function. The Supreme Court made this explicit link to adjudication when it stated that the independence of individual judges is necessary to ensure "the complete liberty of individual judges to hear and decide the cases that come before them". ${ }^{25}$ Judicial independence is clearly linked to the impartial adjudication of disputes; impartiality is the sine qua non of adjudication. When judges are engaged in activities outside of adjudication ("extrajudicial activities"), the premise for their independence - impartiality in dispute adjudication -- is removed. $^{26}$ While new arguments for the independence of judges engaged in extra-judicial activities may exist, they need to be constructed and proffered as they cannot be based on the adjudicatory functions. There are different types of extra-judicial activities and each requires examination through the lens of judicial independence. In the next section I analyze several types of extra-judicial activities and explain how judicial independence is used instrumentally outside of the core adjudicatory function of the judiciary.

\section{The JUdicialization OF POLITICS: JUdiCIAL INDEPENDENCE AS a Public Policy Instrument}

\section{A. THE RISE OF THE JUDGES}

The judiciary in Canada and in most countries is established as a separate branch of government and this idea of separation of powers is an important feature of judicial independence. When judges act outside of their constitutionally mandated judicial role, questions exist regarding the separation of powers and the appropriateness of judges acting in what, strictly speaking, are non-judicial capacities. While the judiciary has acknowledged the

\footnotetext{
${ }^{24}$ See Fraser v. Public Service Relations Board, [1985] 2 S.C.R. 455 at 469-70 (per Dickson C.J.) (explaining that in broad terms, "the role of the judiciary is...to interpret and apply the law; the role of the legislature is to decide upon and enunciate policy; the role if the executive is to administer and implement that policy.”).

${ }^{25}$ Provincial Judges Reference, supra note 9 at para. 123 quoting Beauregard v. Canada, [1986] 2 S.C.R. 56 at 69. See also Provincial Judges Reference, ibid. at para. 10 ("One of these goals is the maintenance of public confidence in the impartiality of the judiciary which is essential to the effectiveness of the court system. Independence contributes to the perception that justice will be done in individual cases.").

${ }^{26}$ On the multiplicity of non-adjudicatory functions performed by judges see generally Peter $\mathrm{H}$. Russell, The Judiciary in Canada: The Third Branch of Government (Toronto: McGraw-Hill Ryerson, 1987) 10-13.

I acknowledge the potential caveat that in Canada judges perform a quasi-executive advisory function through the reference power where with certain narrow exceptions they must accept and opine on various abstract questions put to them by the Governor in Council or the Lieutenant Governor in Council. See e.g. Supreme Court Act, R.S.C. 1985, C. S-25, s. 53 (Reference by Governor in Council), 54 (Reference by Senate or House of Commons); Courts of Justice Act, R.S.O. 1990, c. C-43, s. 8; and Court of Appeal Reference Act, R.S.Q., c. R-23.
} 
existence of potential problems, ${ }^{27}$ serious scrutiny has yet to be undertaken. Extra-judicial activities are not wholly without their potential costs. At this point, I wish to raise some theoretical issues with the use of judges for public policy purposes.

Governments have frequently sought the assistance of judges for public policy purposes. The first conceptual problem arises because of the separation of powers. When judges are engaged in public policy activities for the executive, they are performing executive functions and their mandates are wholly creatures of the executive. ${ }^{28}$ For the most part, the motives of governments have been pure as they sought assistance from members of the judiciary to advise on particular problems. However, at some level, there is a political component to the use of judges by the executive that may be more or less apparent, depending on the circumstances.

On this political level, judicial independence may be used by governments for purposes that are not connected to the core of the principle. Unmoored from its constitutional foundation of the adjudication of disputes, judicial independence may be used for other political ends, namely to deflect attention from the executive branch of government and to provide greater credibility for both the process and the outcome of various non-judicial endeavours. Judges may be used to give the whole process an "aura of independence" so that "the government-established investigation gains the appearance of independence with a federal judge at the helm." ${ }^{29}$ In sum, judicial independence has become a valued political currency in Canada.

As a result of protections developed over time, one of the world's strongest independent judiciaries has arisen in Canada. The character of judicial independence in Canada has enabled the executive branch of government, with the acquiescence of the judiciary, to use judicial independence for other functions that are wholly unconnected to its purposes. Peter Russell has been at the forefront of recognizing and explaining the unique nature of the exercises of judicial power and the issues that arise with it. ${ }^{30}$ Other scholars followed in describing a "judicialization of politics". Michael Mandel has written about the "legalization of politics", Ran Hirschl of

${ }^{27}$ See e.g. Canadian Judicial Council, Ethical Principles for Judges (Ottawa: Canadian Judicial Council, 1998), ch. 2 (Judicial Independence), cmt. 8 (acknowledging the particular risks of judges serving on public inquiries).

${ }^{28}$ See Dixon v. Canada (Commission of Inquiry into the Department of Canadian Forces in Somalia - Létourneau Commission), [1997] F.C.J. No. 985, [1997] 3 F.C. 169 (C.A.) at paras. 12-13.

${ }^{29}$ Tamar Witelson, "Declaration of Independence: Examining The Independence of Federal Public Inquiries" in Allan Manson \& David Mullan, Commission of Inquiry: Praise or Reappraise (Toronto: Irwin Law, 2003) 301 at 350, 319. Cf. Peter H. Russell, The Judiciary in Canada: The Third Branch of Government (Toronto: McGraw-Hill Ryerson, 1987) 12-13 (describing the "aura of impartiality" as one of the reasons for appointing judges to public inquiries); Canadian Bar Association, Report of the Canadian Bar Association Committee on the Independence of the Judiciary in Canada (Ottawa: Canadian Bar Foundation, 1985) 43 (noting that "the presence of a judge lends an aura of reliability and impartiality to the inquiry which is very important").

${ }^{30}$ See e.g. Russell, The Judiciary in Canada, ibid.

31 See Michael Mandel, The Charter of Rights and the Legalization of Politics in Canada, rev. ed. (Toronto: Thomson Educational Publishing, 1994). 
the rise of a "juristocracy",32 and Robert Bork of the "worldwide rule of judges". 33 Each has in common the assertion of an increase in judicial power through the transfer of disputes from the political realm to the judicial. ${ }^{34}$ The phenomenon that I am describing is different. It is the purposeful temporary deployment of judges by the executive for decidedly non-judicial functions. This calculated government "rent-a-judge",35 strategy is explicitly intended to address public policy issues. It does not involve using judges qua judges to adjudicate political disputes to a certain political end, as Mandel, Hirschl, Bork and others describe. Rather, it involves the use of judges by the executive in order to address public policy issues in order to enhance the process or outcome with the trappings of judicial office and of judicial independence. The executive branch draws upon the political capital of judicial independence aware that "the knowledge that a judge is presiding over a public inquiry will add to the public perception that the independence that judges enjoy will be imported into the inquiry context." 36 The executive branch relies both on the public's inability to distinguish between judges acting in judicial and extra-judicial capacities and the judiciary's acquiescence to this arrangement. This use of judicial independence is especially important for fact-finding inquiries but is also useful for controversial policy inquiries. ${ }^{37}$

Recent years have witnessed a significant increase in the use of judges by the executive to address a plethora of public policy issues. What is notable is not only the resurgence of the popularity of public inquiries after a lull of a decade or so but also the expansion of the use of

32 See Ran Hirschl, Towards Juristocracy: The Origins and Consequences of the New Constitutionalism (Cambridge: Harvard University Press, 2004).

${ }^{33}$ Robert H. Bork, Coercing Virtue: The Worldwide Rule of Judges (Toronto: Vintage Canada, 2002).

${ }^{34}$ Mandel argues that the Canadian Charter of Rights and Freedoms has led to a "legalization of politics" in the sense of a transfer of policy making from the political to the legal sphere with concomitant anti-progressive results. Mandel, supra note 31. Looking at the phenomenon on a global scale, Hirschl asserts that constitutional reform has transferred power from representative institutions to courts. He contends that the constitutionalization process is the result of a strategic interplay among hegemonic yet threatened political elites, economic stakeholders and judicial leaders in order to lock in political gains and insulate them from democratic politics. Hirschl, supra note 32. Robert Bork sees the same phenomenon as Mandel and Hirschl but draws opposite conclusions. He argues that around the world judicial activism has resulted in the judicialization of politics and morals with courts around the world siding with left-wing political causes in the international culture wars. Bork, ibid.

${ }^{35}$ To be clear, a sitting judge receives no additional remuneration for agreeing to serve on a commission of inquiry. See Judges Act, R.S.C. 1985, c. J-1, s. 57. The cost of the salary of the judge-commissioner is relatively minor in comparison to the other costs associated with a commission of inquiry.

${ }^{36}$ Tamar Witelson, "Declaration of Independence: Examining The Independence of Federal Public Inquiries" in Allan Manson \& David Mullan, Commission of Inquiry: Praise or Reappraise (Toronto: Irwin Law, 2003) 301 at 349; Tamar Witelson, "Interview with Mr. Justice Gilles Letourneau: Somalia Commission Chair" in Allan Manson \& David Mullan, Commission of Inquiry: Praise or Reappraise (Toronto: Irwin Law, 2003) 361 at 367 (noting that there is "great confusion" between the typical principles of judicial independence and those that apply when a judge sits on a public inquiry).

${ }^{37}$ On the distinction between "fact finding" and "policy" inquiries see O'Connor \& Kristjanson, supra note 5 at 4-6. The current trend is to combine both fact-finding and policy inquiries or to append a policy component onto what is essential a fact-finding inquiry. This was the case in the Gomery Inquiry and the Mulroney-Schreiber Inquiry. 
judges for many public policy exercises on an ad hoc basis. Of further significance is the acquiescence if not the implied support by the judiciary for such extra-judicial activities. The phenomenon is a national one but in addition to the federal scene, I focus on Ontario as the province with which I am most familiar. I turn first to the revival of judge-led public inquiries.

\section{B. The Resurgence of Public InQuiries}

Recent years have witnessed a renaissance in the popularity of public inquiries almost invariably headed by judges, often active ones. In Canada, public inquiries have a long pedigree that pre-dates Confederation in $1867 .^{38}$ They have been termed "a quintessential Canadian policy device", "a time-honoured institutional mechanism for the formulation of public policy in Canada" ${ }^{40}$ "a particularly Canadian disease", ${ }^{41}$ and have played an important role in Canadian political history. ${ }^{42}$ However, until recently, they appeared to be headed for the endangered political species list. A decade ago, commentators were lamenting the apparent demise of public inquiries ${ }^{43}$ they seemed to have fallen into disuse due to neglect or animus by political leaders, both federal and provincial. ${ }^{44}$

However, over the past few years the popularity of public inquiries has rebounded. Since Canadian Prime Minister Jean Chrétien left office in 2003, the federal Government has established no fewer than six public inquiries, which often become associated with the judge or

\footnotetext{
${ }^{38}$ See supra note 4.

${ }^{39}$ A. Wayne Mackay, "Mandate, Legal Foundations, Powers and Conduct of Commissions of Inquiry" in A. Paul Pross, Innis Christie \& John A. Yogis, Commissions of Inquiry (Toronto: Carswell, 1990) 29 at 47.

${ }^{40}$ Robert Centa \& Patrick Macklem, "Securing Accountability through Commissions of Inquiry" A Role for the Law Commission of Canada" in Allan Manson \& David Mullan, Commission of Inquiry: Praise or Reappraise (Toronto: Irwin Law, 2003) 79 at 79 (citing hundreds of reports).

${ }^{41}$ Allan Manson \& David Mullan, "Introduction" in Allan Manson \& David Mullan, Commission of Inquiry: Praise or Reappraise (Toronto: Irwin Law, 2003) 1 at 2.

${ }^{42}$ See Nicholas d'Ombrain, "Public Inquiries in Canada" (1997) 40 Canadian Public Administration 86 at 87 (asserting that federal public inquiries "have marked, if not inspired, some of the pivotal moments in Canada's modern history... They have focused public attention in ways seldom achieved through the normal political process. They have been used consciously to mould public opinion, and they have profoundly influenced the course of public policy and the standards of public life."). However, in retrospect, many public inquiries are more a matter of political expediency than enduring policy or public value. See ibid. at 89 (noting that the Trudeau-Mulroney years were marked by many policy inquiries but few important ones).

${ }^{43}$ See ibid. at 81 (commenting that the capacity of the commission of inquiry to secure governmental accountability "is beginning to falter"); John D. McCamus, "The Policy Inquiry: An Endangered Species?" in Allan Manson \& David Mullan, Commission of Inquiry: Praise or Reappraise (Toronto: Irwin Law, 2003) 211.

${ }^{44}$ In particular, as discussed below, the federal Liberal government of Jean Chrétien and the Ontario provincial government of Progressive Conservative Mike Harris both disfavoured public inquiries.
} 
leading figure at the center of the inquiry: $:^{45}$ Arar (announced in January 2004, reported in September 2006), Gomery (February 2004, reports delivered in November 2005 and February 2006), Iacobucci (December 2006, report delivered October 2008), ${ }^{46}$ Air India (established May 2006, report expected 2009), ${ }^{47}$ Indian Residential Schools Truth and Reconciliation Commission (established April 2008, expected to last five years) ${ }^{48}$ and Mulroney-Schreiber (established June 2008). ${ }^{49}$ This represents an average of more than one per year, but as public inquiries extend over the course of several years, there are often a number of public inquiries operating at once. Thus, in the fall of 2008, Canadians were digesting the report of Mr. Justice Iacobucci in his inquiry into the actions of Canadian officials in relation to three Canadians who were tortured abroad, ${ }^{50}$ were awaiting the report of Mr. Justice Major in the Air India Inquiry, anticipating the start of hearings in the inquiry into the dealings of former Prime Minister Brian Mulroney with German businessman and arms dealer Karlheinz Schreiber and watching the possible implosion of the Truth and Reconciliation Commission for Indian Residential Schools with the sudden and dramatic resignation of its Chair, Ontario Court of Appeal Justice Harry LaForme. ${ }^{51}$ These only cover the federally-appointed inquiries; as discussed below, several provincial inquiries were ongoing during the same period. Thus, it is only half-jokingly that one Canadian Senator quipped that working in Ottawa, "we have elections, budgets, Throne Speeches-just to fill the time between inquiries." 52

A similar theme emerges from Canada's largest province, Ontario, where the Progressive Conservative government of Premier Mike Harris (1995-2003) shared with its federal Liberal

\footnotetext{
${ }^{45}$ See Mackay, supra note 39 at 31.

${ }^{46}$ Internal Inquiry into the Actions of Canadian Officials in Relation to Abdullah Almalki, Ahmad Abou-Elmaati and Muayyed Nureddin (Iacobucci Internal Inquiry), online: http://www.iacobucciinquiry.ca

${ }^{47}$ Commission of Inquiry into the Investigation of the Bombing of Air India Flight 182 (The Hon. John C. Major, Q.C., Commissioner), online: http://www.majorcomm.ca/en/

${ }^{48}$ Indian Residential Schools Truth and Reconciliation Commission, online: http://www.trc-cvr.ca/indexen.html

${ }^{49}$ Commission of Inquiry into Certain Allegations Respecting Business and Financial Dealings Between Karlheinz Schreiber and the Right Honourable Brian Mulroney (The Hon. Jeffrey J. Oliphant, Commissioner), online: http://www.oliphantcommission.ca

${ }^{50}$ See Internal Inquiry into the Actions of Canadian Officials in Relation to Abdullah Almalki, Ahmad AbouElmaati and Muayyed Nureddin (Iacobucci Internal Inquiry), online: http://www.iacobucciinquiry.ca. See Colin Freeze, "Torture report urges Ottawa to better protect rights" (22 October 2008) Globe and Mail.

${ }^{51}$ See Joe Friesen, "Resignation paralyzes residential schools commission" Globe and Mail (21 October 2008) A1; Joe Friesen, Jacquie McNish \& Bill Curry, "Native leaders divided over future of residential schools panel" Globe and Mail (22 October 2008) A4; Joe Friesen, "AFN meddling blamed for exit of commission's chairman" (23 October 2008) A1; Joe Friesen, "Judicial Independence key to LaForme's resignation" Globe and Mail (24 October 2008) A4.

${ }^{52}$ Mitchell Raphael, "Filling in Time Between Inquiries" Macleans (10 December 2007) 11 (The remark was attributed to Senator Hugh Segal at the Churchill Society for the Advancement of Parliamentary Democracy's $24^{\text {th }}$ annual dinner). Along similar lines, the National Post held a contest in 2007 inviting readers to come up with a motto for Canada in six words or less. One of the top 10 nominees included "From inquiry to inquiry." See "And the winner is ..." National Post (8 December 2007) (the winner was "Canada—a home for the world").
} 
counterpart an antipathy towards public inquiries. For the duration of its two terms in government, the Harris Government resisted calls for an inquiry into the 1995 shooting death of Native protester Dudley George at Ipperwash Park. However, when seven people died and over 2,300 became sick from e-coli in the Town of Walkerton's drinking water, Premier Harris appointed Associate Chief Justice Dennis O'Connor to head a public inquiry. Justice O'Connor's administration of the public inquiry was widely praised and it quickly became the gold standard against which future public inquiries were to be measured. ${ }^{53}$ It also became an idealized model of a public inquiry: a strong and compassionate judge running an effective public inquiry and delivering a relevant report within a reasonable period of time on a subject that could not be considered "inside politics" or inherently partisan. ${ }^{54}$ At the end of the mandate of Harris's successor, Premier Ernie Eves, another public health crisis of international proportions, SARS, led to the appointment of Justice Archie Campbell to head a commission of inquiry on that subject. ${ }^{55}$

For eight years, Ontario's provincial Liberal opposition had called for a public inquiry into the death of Dudley George and promised in its 2003 election platform to convene one. After it was elected in October 2003, one of the first acts of the new Liberal government in Ontario was to appoint the former Chief Justice of Ontario's provincial court, the Honourable Sidney Linden, to head a public inquiry into events at Ipperwash and he was given a broad mandate to also make recommendations regarding avoiding violence in similar circumstances. ${ }^{56}$ The Ontario Liberals followed soon after with the appointment of Justice Roland Haines to conduct a review of Ontario's meat inspection system. ${ }^{57}$ The Meat Review was then followed by a full-fledged public inquiry into allegations of sexual abuse in Cornwall, Ontario ${ }^{58}$ and the

\footnotetext{
${ }^{53}$ See Janice Tibbetts, “Judges' roles in probes debated” The National Post (3 November 2008).

${ }^{54}$ This inquiry had a partisan political element in that various political parties sought standing to argue that budget cuts made by a particular political party in power were more responsible for lax regulation than budget cuts made during their tenure in power.

55 See Order in Council 1230/2003 (Ontario), contained as Appendix B to the SARS Commission Interim Report, online: http://www.health.gov.on.ca/english/public/pub/ministry_reports/campbell04/campbell04.pdf

${ }^{56}$ See Ministry of the Attorney General, Press Release, “Ontario Government Announces Public Inquiry into the Death of Dudley George" (12 November 2003), http:/www.attorneygeneral.jus.gov.on.ca/english/news/2003/20031112-ipperwash.asp. Some people saw Justice Linden engaged in a mini-Royal Commission on Aboriginal Peoples, a reference to the federal commission between 1991 and 1996 which produced a five-volume 4000 page report at a cost of $\$ 60$ million. With the broad ranging recommendations of the four volume Ipperwash Inquiry released in May 2007, three and a half years and \$13.3 million later, there is some validity to this assertion. For all information related to the Ipperwash Inquiry see www.ipperwashinquiry.ca

${ }^{57}$ See Ontario Ministry of the Attorney General, Press Release, "McGuinty Government Appoints Senior Judge to Examine and Report on Meat Inspection System" (9 January 2004), online: http:/www.attorneygeneral.jus.gov.on.ca/english/news/2004/20040109-meat-nr.asp

58 The Cornwall Inquiry was appointed in April 2005. See generally http:/www.cornwallinquiry.ca/en/. In October 2008, Ontario's Attorney General set a deadline for the completion of hearings (January 2009) and the issuance of the inquiry's report (July 2009). See Canadian Press, “Ont. orders inquiry into sex abuse allegations in Cornwall to
} 
Inquiry into Pediatric Forensic Pathology in Ontario headed by Justice Stephen Goudge who delivered his report in October 2008. ${ }^{59}$ Earlier in the decade, the City of Toronto got into the act, appointing a commission of inquiry into a computer leasing scandal. ${ }^{60}$

The story repeats itself across the country. In September 2008, the Saskatchewan Commission of Inquiry into the Wrongful Conviction of David Milgaard released an 815 page report at a cost of $\$ 10$ million. ${ }^{61}$ Several years earlier Saskatchewan had held an inquiry into the death of Neil Stonechild. ${ }^{62}$ In Manitoba, public inquiries into two wrongful convictions reported in 2007 and $2008,{ }^{63}$ while a commission of inquiry into the province's child welfare systems is expected to commence in 2009. ${ }^{64}$ British Columbia has also had two public inquiries over the past several years: the Frank Paul Inquiry into the death of a Native man after being released from police custody ${ }^{65}$ and an inquiry into the taser death of a Polish man at the Vancouver International Airport. ${ }^{66}$ New Brunswick had not had a public inquiry in over a decade, when in February 2008, the government established one to review the actions of a former pathologist in more than 24,000 patient cases. ${ }^{67}$ In Newfoundland and Labrador, there have been public

\begin{tabular}{llllll}
\hline wrap up & by & online:
\end{tabular}

http://canadianpress.google.com/article/ALeqM5iH9vTc9RPMqMENt4pRA0XLFmI5Kw

${ }^{59}$ See Inquiry into Pediatric Forensic Pathology in Ontario (The Hon. Stephen T. Goudge, Commissioner), online: http://www.goudgeinquiry.ca/

${ }^{60}$ Toronto Computer Leasing Inquiry (The Hon. Madam Justice Denise Bellamy, Commissioner), online: http://www.toronto.ca/inquiry/inquiry_site/index.html

${ }^{61}$ See John Weidlich, "'The criminal justice system failed David Milgaard': inquiry's report", CBC News (26 September 2008), online: http://www.cbc.ca/canada/story/2008/09/26/milgaard-advance.html?ref=rss. See also The Commission of Inquiry into the Wrongful Conviction of David Milgaard (The Hon. Mr. Justice Edward P. MacCallum, Commissioner), online: www.milgaardinquiry.ca.

${ }^{62}$ See Report of the Commission of Inquiry into Matters Relating to the Death of Neil Stonechild (The Hon. Mr. Justice D.H. Wright, Commissioner) (2004), online: http://www.stonechildinquiry.ca/. Cf. Report of the Commission of Inquiry into Matters Relating to Safety of the Public Drinking Water in the City of North Battleford, Saskatchewan (The Hon. Robert D. Laing, Commissioner) (2002).

${ }^{63}$ Report of the Commission of Inquiry into Certain Aspects of the Trial and Conviction of James Driskell (Hon. Patrick J. Lesage, Q.C., Commissioner) (2007), online: http://www.driskellinquiry.ca/; Report of the Taman Inquiry into the Investigation and Prosecution of Derek Harvey-Zenk (The Hon. Roger Salhany, Q.C., Commissioner) (2008), online: http://www.tamaninquiry.ca/.

${ }^{64}$ See Commission of Inquiry into the Death of Phoenix Sinclair -per: Evidence Act; "Manitoba couple sentenced to life for death of Phoenix Sinclair" CBCnews.ca (12 December 2008), online: http://www.cbc.ca/canada/manitoba/story/2008/12/12/mb-sinclair-trial.html?ref=rss

${ }^{65}$ See Inquiry into the Death of Frank Paul (The Hon. William H. Davies, Q.C., Commissioner), online: http://www.frankpaulinquiry.ca/

66 See Braidwood Inquiries (The Hon. Thomas R. Braidwood, Q.C., Commissioner), online: http://www.braidwoodinquiry.ca/

${ }^{67}$ See Commission of Inquiry into Pathology Services at the Miramichi Regional Health Authority (The Hon. Paul S. Creaghan, Commissioner), online: http://www.miramichicommission.ca/index.html. See Adam Huras, "Authority blamed for letting Menon practice" (New Brunswick) Telegraph Journal (11 Dec. 2008) A2, online: http://telegraphjournal.canadaeast.com/search/article/508446. 
inquiries into the administration of justice ${ }^{68}$ and faulty breast cancer test results ${ }^{69}$ while in Nova Scotia a commission of inquiry investigated the youth criminal justice system. ${ }^{70}$. In each of these cases, federal and provincial, the public inquiry was or is being headed by a judge. Amidst all of this, Quebec stands as an outlier; not in its resistance to public inquiries but in its willingness to hold public inquiries headed by non-judges. ${ }^{71}$

There is a certain paradox in using judges to head public inquiries. On a separation of powers level, inquiries are instruments of the executive, yet they are most frequently headed by judges. $^{72}$ Often public inquiries are called "to remove an unpleasant controversy from the political agenda., ${ }^{, 73}$ It is generally recognized that there is a potential risk at least to the individual judges who decide to head up a public inquiry. Canadian constitutional scholar MacGregor Dawson explained this well in 1957 when he cautioned:

There would seem to be little purpose in taking elaborate care to separate the judge from politics and to render him quite independent of the executive, and then placing him in a position as a Royal Commissioner where his impartiality may be attacked and his findings - no matter how correct and judicial they may be - are liable to be interpreted as favouring one political party at the expense of the other. For many of the inquiries

\footnotetext{
${ }^{68}$ Lamer Inquiry Report into the Administration of Justice, online: http://www.justice.gov.nl.ca/just/lamer/

${ }^{69}$ Commission of Inquiry into Hormone Receptor Testing (The Hon. Justice Margaret A. Cameron, Commissioner), online: http://www.cihrt.nl.ca/

${ }^{70}$ Nunn Commission of Inquiry, Spiraling out of Control: Lessons Learned from a Boy in Trouble: Report of the Nunn Commission of Inquiry (Nova Scotia: Nunn Commission of Inquiry, 2006). Speaking in October 2007 in Nova Scotia, Justice O'Connor \& Freya Kristjanson reported on two additional public inquiries in that province that were then ongoing: one involving the remuneration of elected provincial officials, and another under the Municipal Conflict of Interest Act. See O’Connor \& Kristjanson, supra note 5.

${ }^{71}$ For example, former Quebec Premier Pierre Marc Johnson headed a public inquiry into the collapse of an overpass in Laval that resulted in the death of five persons. Historian and Sociologist Gérard Bouchard and Philosopher Charles Taylor headed a very controversial commission into reasonable accommodation of religious minorities in Quebec. See Consultation Commission on Accommodation Practices Related to Cultural Differences, online: http://www.accommodements.qc.ca/index.html. However, in December 2008, the Quebec government appointed Quebec Court Judge Robert Sansfaçon to conduct a public inquiry into the shooting deaths of young men from minority groups at the hands of the Montreal police. See Sue Montgomery, "Quebec launches public inquiry into Villanueva shooting" Montreal Gazette (2 December 2008), online: http://www.montrealgazette.com/story print.html?id=1018668\&sponsor=

72 Allan Manson \& David Mullan, "Introduction” in Allan Manson \& David Mullan, Commission of Inquiry: Praise or Reappraise (Toronto: Irwin Law, 2003) 1 at 5.

${ }^{73}$ Robert Centa \& Patrick Macklem, "Securing Accountability through Commissions of Inquiry" A Role for the Law Commission of Canada" in Allan Manson \& David Mullan, Commission of Inquiry: Praise or Reappraise (Toronto: Irwin Law, 2003) 79 at 89 (citing P. Desbarats, "The Independence of Public Inquiries: Dixon v. Canada" (1997) 36 Alta. L. Rev. 252 at 253).
} 

or boards place the judge in a position where he cannot escape
controversy: $\ldots{ }^{74}$

Professor Dawson's warnings ring true today, over a half century after he wrote these words. There is a real risk of judicial entanglement in highly political disputes when judges agree to participate in public inquiries. In the United States, this recognition has led to an established bar and bench to view judicial involvement in public inquiries as improper judicial conduct. $^{75}$ In Australia, the propriety of such judicial involvement is strongly contested, with some even asserting that it is unconstitutional. ${ }^{76}$ Canada takes a different approach. While the federal Judges Act generally prohibits extra-judicial activities, it allows them if they are expressly authorized by legislation of the relevant federal or provincial legislature. ${ }^{77}$ To date, Canadian judges and lawyers have not seriously addressed the separation of powers concerns that have animated debates in other jurisdictions. ${ }^{78}$

The Canadian Judicial Council - the body statutorily charged with overseeing the conduct of Canada's federally appointed judges - acknowledged the issue over a decade ago. In 1998 , it recognized the possible pitfalls of judges sitting on public inquiries in its ethical guidelines for judges, stating that when judges are considering a request to serve as inquiry commissioners, they "should think carefully about the implications for judicial independence of

${ }^{74}$ MacGregor Dawson, The Government of Canada, $3^{\text {rd }}$ ed. (Toronto: University of Toronto Press, 1957) 482. Dawson further stated that "It has been proved time and again that it many of these cases the judge loses in dignity and reputation, and his future is appreciably lessened thereby. Moreover, if the judge remains away from his regular duties for very long periods, he is apt to lose his sense of balance and detachment; and he finds that the task of getting back to normal and of adjusting his outlook and habits of mind to purely judicial work is by no means easy." Ibid. These passages from Dawson are quoted with approval by the Canadian Judicial council in its Ethical Principles for Judges (Ottawa: Canadian Judicial Council, 1998) ch. 4 (Judicial Independence), cmt. 8, n. 9.

${ }^{75}$ American Bar Association, Model Code of Judicial Conduct (2007), Rule 3.4 (“[a] judge shall not accept appointment to a governmental committee or board, or other governmental position, unless it is one that concerns the law, the legal system, or the administration of justice.").

${ }^{76}$ See Wilson v. Minister for Aboriginal \& Torres Strait Islander Affairs ("Hindmarsh Island Bridge case"), [1996] HCA 18, (1996) 189 CLR 1 (holding unconstitutional the appointment of a Justice of the Federal Court of Australia to conduct a review of a case involving a claim that Aboriginal interests were affected by a proposed bridge). See generally Sherman, "Should Judges Conduct Royal Commissions?" (1997) 8 PLR 5; Beatson, "Should Judges Conduct Public Inquiries?" (2005) 121 LQR 221; Wheeler, "The Use of Federal Judges to Discharge Executive Functions: The Justice Matthews Case" (1996) 11 AIAL Forum 1. Thanks to Greg Taylor for bringing these and other sources to my attention.

${ }^{77}$ See Judges Act, R.S.C. 1985, c. J-1, ss. 55-56.

${ }^{78}$ Over 20 years ago, the Canadian Bar Association recognized many of the potential problems with judges heading public inquiries. See Canadian Bar Association, Report of the Canadian Bar Association Committee on the Independence of the Judiciary in Canada (Ottawa: Canadian Bar Foundation, 1985) 43. A Committee of the CBA recommended that generally judges should not be asked to participate in commissions of inquiry except where "the nature of the matter under investigation makes the choice of a judge as a commissioner of inquiry particularly appropriate." Ibid. at 59. This CBA Committee seemed to be recommending that the default rule be that a judge not participate in a commission of inquiry. This discussion was part of a broader report on the independence of the judiciary undertaken in the context of proposed statutory and constitutional reforms which did not come to fruition. 
accepting the appointment.",79 The Canadian Judicial Council noted that there were examples of "Judicial Commissioners becoming embroiled in public controversy and being criticized and embarrassed by the very governments that appointed them." The guideline concluded by recommending that the terms of reference and other conditions "should be examined carefully so as to assess their compatibility with the judicial function." $" 80$ This is good advice, but there is little indication that it has been followed. Moreover, the guidelines also indicate that individual judges who are approached to serve as commissioners should consult with their chief justices. This indicates that the decision to serve as a commissioner has both an individual and an institutional component and that both elements should be considered in a decision by a particular judge to serve as a commissioner.

The guidelines referred to above were the result of a resolution adopted by the Canadian Judicial Council in March 1998 entitled "Position of the Canadian Judicial Council on the Appointment of Federally-Appointed Judges to Commissions of Inquiry" which provided more specific guidance on this issue. ${ }^{81}$ This statement had a number of relevant components: (1) every request for a judge to take on an extra-judicial function should be made in first instance to the chief justice of the relevant court; (2) such request should be accompanied by a reference to the statutory authority for the proposed appointment; (3) the request be accompanied with the proposed terms of reference for the inquiry and indication of the time limit for it; (4) sufficient time be given for the chief justice to discuss fully the request with the relevant judge whose services are requested; (5) the chief justice, in consultation with the judge in question, should consider whether the judge's absence would significantly impair the work of the court; and (6) the chief justice and the judge should consider whether accepting the proposed appointment could impair the future work of the judge as a member of the court. ${ }^{82}$ In particular, they should consider:

- Whether the subject-matter of the inquiry essentially requires advice on public policy or involves issues of an essentially partisan nature;

- Whether it essentially involves an investigation into the conduct of agencies of the appointing government;

- Whether the inquiry is essentially an investigation of whether particular individuals have committed a crime or a civil wrong;

- Who is to select commission counsel and staff;

- Whether the proposed judge is specially required for this inquiry, through particular knowledge or experience, or whether a retired or supernumerary judge would be suitable; and

${ }^{79}$ Canadian Judicial Council, Ethical Principles for Judges (Ottawa: Canadian Judicial Council, 1998), ch. 2 (Judicial Independence), cmt. 8.

${ }^{80} \mathrm{Ibid}$.

${ }^{81}$ Canadian Judicial Council, Position of the Canadian Judicial on the Appointment of Federally-Appointed Judges to Commissions of Inquiry, approved at is March 1998 mid-year meeting, online: http://www.cjcccm.gc.ca/cmslib/general/news_pub_other_PositionCJC_1998 en.pdf.

${ }^{82}$ Ibid. 
- If the inquiry requires a legally-trained commissioner, should the court feel obliged to provide a judge or could a senior lawyer perform this function equally well? ${ }^{83}$

After the Canadian Judicial Council's statement was adopted, Chief Justice Antonio Lamer, as head of the Council, sent a memorandum to all First Ministers expressing concerns about the use of federally-appointed judges as commissioners in public inquiries on both independence and operational grounds and attaching the statement.

The Canadian Judicial Council's actions in 1998 were an excellent recognition of the problems associated with extra-judicial activities of judges. However, the actions of the Canadian Judicial Council and the Chief Justice in 1998 coincided with what turned out to be a period of hiatus in public inquiries and the warnings seemed to have disappeared into the wind. As discussed above, this was a period during which the leaders of the two largest governments in Canada expressed a strong antipathy towards public inquiries. ${ }^{84}$ As discussed in the next section, there is good reason to revisit Chief Justice Lamer's memorandum and the Canadian Judicial Council's guidelines and take their warnings seriously.

Moreover, the Canadian Judicial Council's guidelines give the misleading impression that public inquiries are set up through a careful process of deliberation and consultation. While this may be the case, it rarely is so. ${ }^{85}$ More often than not, public inquiries are established under the heat of political pressure and the selection of the judge becomes a matter of political urgency

83 Ibid.

${ }^{84}$ In his memoirs, former Prime Minister Jean Chrétien explained at length: "For the opposition parties, calling for a public inquiry is usually an easy way to dig up dirt or keep a hot issue on the front burner after they've exhausted their own supply of facts and questions. For the government, giving in to the calls is often a mechanism to do nothing, to dodge responsibility, or to postpone a controversial decision until after the next election. Very few of these inquiries in my experience have ever been of much use, and those few were valuable only because they didn't turn into television soap operas. If there's a problem, you should face up to it and make a decision. If you need more information, you can always ask the department to give you a full report. If you need an independence point of view, you can ask someone to carry out an investigation without a lot of fanfare, as happened when I asked Robert Nixon, a former Treasurer of Ontario, to look into the circumstances around the Tories' deal to privatize Toronto's Pearson International Airport, which had been an issue in the 1995 election campaign. If you want to examine a broad social issue, you can set up a royal commission, as we did with health. But it is in the nature of public inquiries to get turned into show trials, kangaroo courts, and political entertainment. The rules of evidence don't have to be respected as they are in a court. There's not the same right of due process or even the same process to protect the innocent during the investigation into a possible wrong-doing. Scores of reputations are shattered for not good cause; people lose their jobs merely because their names happened to be mentioned in passing; and the entire public service is tarred by gossip and innuendo." See Jean Chrétien, My Years as Prime Minister (Toronto: Alfred A. Knopf, 2007) 187-88. This statement was written at a time during which the former Prime Minister was embattled in litigation against Judge Gomery so they should not be automatically accepted at face value. See Chrétien v. Canada (Commission of Inquiry into the Sponsorship Program and Advertising Activities, Gomery Commission), [2008] F.C.J. No. 973, 2008 FC 802 [Chrétien v. Canada]. However, Mr. Chrétien's pattern of resistance towards public inquiries during the course of his prime ministership (1993-2003) lends credence to his assertions above.

${ }^{85}$ See d'Ombrain, supra note 5 at 93 (stating that most investigative commissions of inquiry are set up very quickly, usually in response to intolerable political pressure and are invariably headed by judges). 
and expediency rather than a policy ideal. ${ }^{86}$ Since the Canadian Judicial Council's statement was issued over a decade ago, there has been no publicly acknowledged instance of either a provincial or federal government being unable to obtain the necessary approvals in order to get a federally-appointed judge to head a commission of inquiry. While certainly it is likely the case that chief justices have been unwilling to release particular judges due to judicial workload and that individual judges have turned down governments' requests to head a public inquiry, there always appears to be a judge willing to take on the task with the approval of his or her chief justice. At the end of the day, that is usually what governments are seeking: a generic judge that can then be used by governments in order to attach the label "independent" to the inquiry being established. In fact, this is how the calling of most public inquiries work in practice. First, the government announces its intention to call a public inquiry which is often referred to as "a judicial inquiry"; subsequently, they announce the name of the judge and the terms of reference. In most cases, the judge is unknown to the public and to the press and information about who that person is comes out later; who they are is secondary to what they are - a judge who carries the political capital of judicial independence that immediately gives the process credibility as "independent" ${ }^{87}$ Despite the obvious pitfalls for judges and for the judiciary in heading public inquiries, extrajudicial functions of judges have continued to expand in Canada over the past decade as discussed in the next section.

\section{Beyond Public Inquiries: Judges for ExeCutive Functions}

There is a long history in Canada of assigning judges to extra-judicial functions beyond the realm of public inquiries The most notable such responsibility is the appointment of the Chief Justice of Canada as Deputy Governor General, or in the case of the absence or unavailability of the Chief Justice, the most senior available puisne justice. This appointment was formalized in the 1947 Letters Patent Constituting the Office of the Governor General of Canada. ${ }^{88}$ The Governor General exercises both legislative powers (the granting of royal assent for all legislation) as well as executive ones (e.g. selection of the Prime Minister, prorogation, the dissolution of Parliament). Her role is largely ceremonial and the powers that she exercises are almost exclusively based on the advice of her ministers, notably the Prime Minister. However, in critical constitutional situations such as the one that Canada faced in late 2008, the

\footnotetext{
${ }^{86}$ See ibid. ("The decisions about these inquiries and selection of commissioners is often made in a disorderly way.").

${ }^{87}$ Exceptions exist where governments do in fact seek the expertise of a particular judge. The federal Government's appointment of Associate Chief Justice Dennis O'Connor to conduct the Arar Inquiry is case in point and likely resulted from Justice O'Connor's successful handling of the Walkerton Inquiry in Ontario.

${ }^{88}$ Letters Patent Constituting the Office of Governor General of Canada, art. VIII (1947), reprinted in Bernard W. Funston \& Eugene Meehan, Canadian Constitutional Documents Consolidated, $2^{\text {nd }}$ ed. (Toronto: Thomson/Carswell, 2007) 346 at 348.
} 
Governor General is called upon to exercise her independent discretion as to how to act. ${ }^{89}$ And if she were unavailable or out of the country, the Chief Justice (or another Supreme Court justice) would exercise such decidedly non-judicial powers. ${ }^{90}$ The provinces have followed this model with their Chief Justices filling the Lieutenant-Governor's role in case of absence or unavailability.

Similarly, judges have long headed electoral boundary commissions in Canada. This function is not a new one and unlike public inquiries, the mandate, duration and operation of such commissions follow a general and predictable format. ${ }^{91}$ Because of their direct link to electoral politics, electoral boundary commissions are transparently political and the opportunities for political involvement are established and predictable: testimony during such commissions and the legislature's response after the commissions deliver their report. Recent scrapes between the government and electoral commission in British Columbia, highlight the political stakes in the process. ${ }^{92}$

In recent years, there has been a significant expansion of the use of judges, retired and active, for both administrative and executive functions. Especially notable is the dramatic expansion of judges for public policy roles outside of public inquiries. This judicialization of the policy and administrative spheres is a function of both supply and demand. On the supply side, a larger pool of former federally-appointed judges has developed due to early and active retirements. ${ }^{93}$ The nature of judicial retirement has changed, as has the character of retirement generally in society. The old model of the retired judge was of the eminence grise who perhaps joined a law firm and dispensed wise counsel to younger lawyers or gave after dinner speeches at bar association functions. The new model of judicial retirement is of an active second career, either back at the bar or in the realm of public policy.

On the demand side, there are a number of reasons why such judges are especially popular choices for governments. The demand for actors outside of government such as judges to conduct both targeted and general policy reviews has increased as the supply of other possible

\footnotetext{
${ }^{89}$ See generally Peter H. Russell \& Lorne M. Sossin, eds., Parliamentary Democracy in Crisis: The Dilemmas, Choices and Future of Parliamentary Government in Canada (Toronto: University of Toronto Press, forthcoming 2009). The most famous case is of course the King-Byng Crisis of 1926. See Eugene Forsey, The Royal Power of Dissolution in the Commonwealth (Toronto: Oxford University Press, 1938). On another issue see e.g. Adam M. Dodek, "Rediscovering Constitutional Law: Succession upon the Death of the Prime Minister" (2000) 49 UNBLJ 33.

${ }^{90}$ At the least it is notable that there has been no serious discussion as to the propriety of the Chief Justice (or a puisne judge) exercising such non-judicial functions, on separation of powers and other grounds.

${ }^{91}$ See generally John C. Courtney, Commissioned Ridings: Designing Canada's Electoral Districts (Montreal \& Kingston: McGill-Queen's University Press, 2001).

92 See CBC News, "BC Liberals promise free vote over cuts to rural ridings" (15 February 2008), online: http://www.cbc.ca/canada/british-columbia/story/2008/02/15/bc-free-vote-on-ridings.html

${ }^{93}$ By virtue of s. 99(2) of the Constitution Act, 1867, federally-appointed judges must retire at age 75. Similar restrictions exist for provincial court judges. See e.g. Courts of Justice Act, R.S.O. 1990, c. C-43, s. 47.
} 
candidates to conduct such reviews has declined over time. Across Canada, the independent policy making capacity of non-governmental actors was dealt a heavy blow in the last decade of the last century and the first decade of this century. Federal and provincial governments disbanded law commissions and reduced funding to other arm's length organizations that produced policy work. Canada has never had the same level of strong independent public policy think tanks as in the United States. Canada has good public policy institutes, but no equivalents to the Rand Corporation, the American Enterprise Institute, the Brookings Institute or the Pew Research Center which have exerted a strong influence on the formation of American policy. ${ }^{94}$ Political parties have very limited research and policy capabilities ${ }^{95}$ and the internal policymaking capacities of governments were weakened during government cutbacks in the 1990s. At the same time, governments have been unwilling to use legislative tools such as committees of the Legislature in order to engage in investigative or policy-making functions, due in part to the decline in public perceptions of our elected officials. ${ }^{96}$ In sum, in Canada, the public policy capacities both inside and outside government are limited or have weakened and a strong negative perception exists regarding government's ability to address an issue whenever a specific problem arises. Government institutions have weakened in favour of the rise of a cadre of "independent" officials and bodies and the use of judges for such activities falls within this category.

In the realm of administrative functions, retired judges are favored for new positions that have been created across the country such as parliamentary ethics or integrity officers, ${ }^{97}$ and

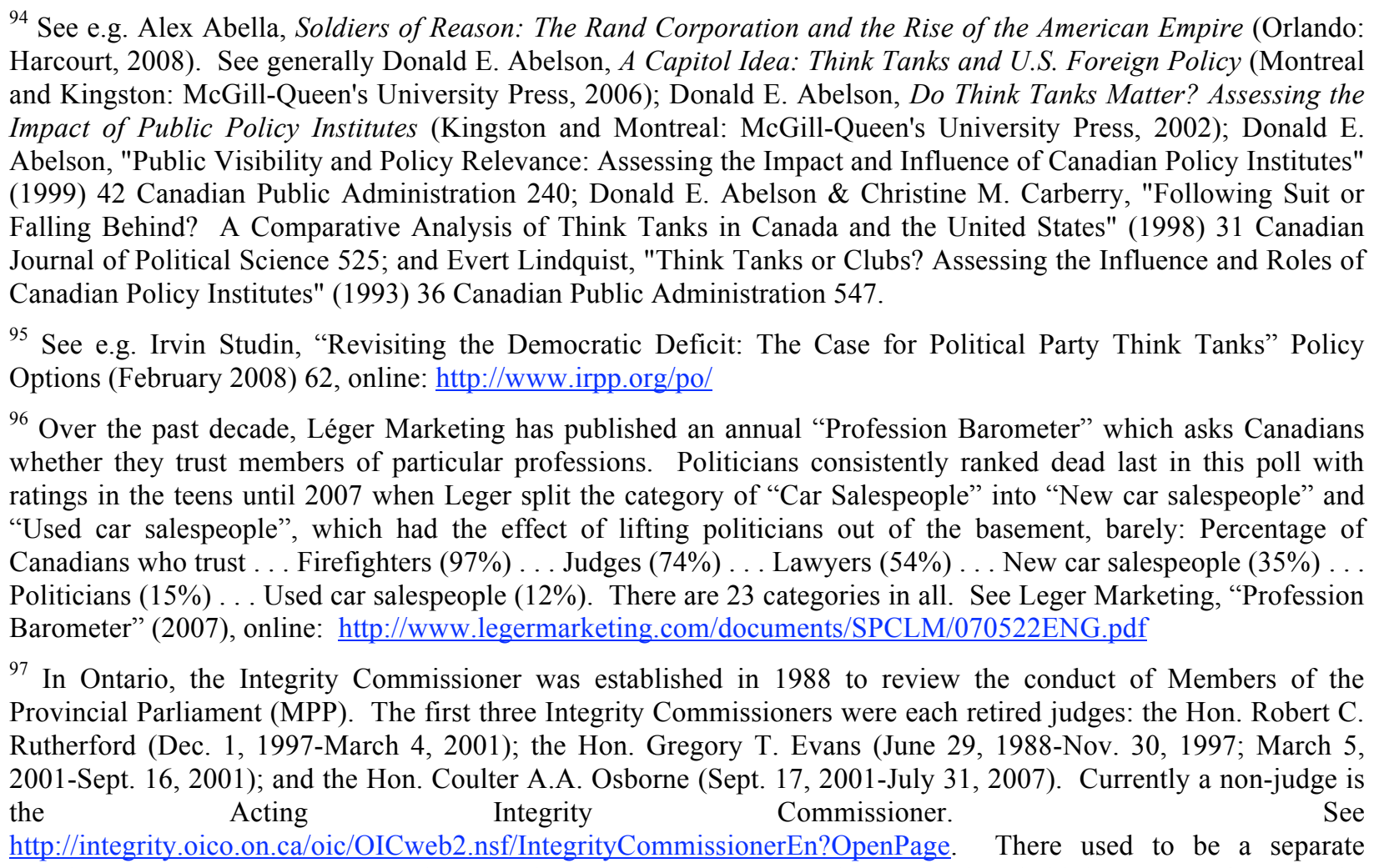
Conflict of Interest Commissioner designated for the staff of MPPs and retired judges held this position but now the 
child advocates. $^{98}$ In Ontario, they have also become popular choices as appointees to administrative tribunals such as the Human Rights Tribunal of Ontario, ${ }^{99}$ the Ontario Review Board, ${ }^{100}$ the Consent and Capacity Board ${ }^{101}$ and the Ontario Securities Commission. ${ }^{102}$ Judges are natural candidates for such offices because they often involve the exercise of quasi-judicial powers.

In addition, the executive is also increasingly turning to judges to conduct various sorts of reviews which fall short of public inquiries. These share some characteristics of public inquiries, however judicial reliance on the executive is usually much greater in terms of support, research, budget, staffing, etc. On these sorts of reviews, it is useful to distinguish between "targeted reviews" which relate to a specific incident or issue and broader policy reviews. On targeted reviews, a retired judge advised the federal Minister of Justice on the possible wrongful conviction of Stephen Truscott. ${ }^{103}$ After the federal Minister ordered a reference to the Court of

Integrity Commissioner has jurisdiction for both MPPs and their staff. The new Conflict of Interest Commissioner has jurisdiction over the Public Service and the first person appointed to this role is the Hon. Sydney Linden who, among other things, was the Commissioner for the Ipperwash Inquiry. In both New Brunswick and Nova Scotia, the Conflict of Interest Commissioner is currently a retired judge. See "Profile", New Brunswick Conflict of Interest Commissioner (The Hon. Patrick A.A. Ryan), online: http://www.gnb.ca/legis/conflict/profile-e.asp and Nova Scotia House of Assembly, "Conflict of Interest Commissioner" (The Hon. D. Merlin Nunn), online: http://www.gov.ns.ca/legislature/house of assembly/conflict.html. In other provinces, while a non-judge currently holds office, prior occupants have been judges.

${ }^{98}$ In British Columbia, the government established the office of the Representative for Child and Youth after an independent review conducted by the Hon. Ted Hughes. An all-party committee of the Legislature appointed Judge Mary Ellen Turpel-Lafond of the Saskatchewan Provincial Court as the first Representative. See British Columbia, Representative for Child and Youth, History, online: http://www.rcybc.ca/Content/AboutRCY/History.asp. Judge Turpel-Lafond is on a five year leave of absence from her court. See British Columbia, Representative for Child and Youth, Mary Ellen online: http://www.rcybc.ca/Images/Who\%20We\%20Are/METL\%20Bio\%20Final.pdf.

${ }^{99}$ Former Supreme Court of Canada Justice Peter Cory and former Ontario Court of Appeal Justice Alvin Rosenberg were past members of the Human Rights Tribunal of Ontario. See Human Rights Tribunal of Ontario, List of Members, online: http://www.hrto.ca/NEW/about/members.asp (listing the Hon. Alvin Rosenberg, Q.C. as a member as of January 31, 2009).

${ }^{100}$ The Ontario Review Board is currently chaired by Mr. Justice Douglas Carruthers. Its members include retired judges Justices Michael Forestell, Douglas Coo, John McCombs, John O’Driscoll, Nicholson McRae as well as former Master of the Superior Court, Ross Linton See Ontario Review Board, Agency Members Biographies, online: https://www.pas.gov.on.ca/scripts/en/bios.asp?minID=49\&boardID=853\&persID=112277\#1.

${ }^{101}$ Ontario's Consent and Capacity Board is chaired by Justice Edward Ormston. Vice Chairs include former Chief Justice of the Ontario Superior Court, the Hon. Patrick LeSage. Its members include retired justice Douglas Coo. See Ontario, Consent and Capacity Board, Agency Members Biographies, online: https://www.pas.gov.on.ca/scripts/en/bios.asp?minID=49\&boardID=876\&persID=136003\#1

${ }^{102}$ Former Chief Justice Patrick LeSage is a Commissioner of the Ontario Securities Commission. See http://www.osc.gov.on.ca/About/Governance/Commission/ga commission members.jsp\#pjles

103 In 2002, Minister of Justice Martin Cauchon appointed retired Justice Fred Kaufman to conduct a review. See Canada, Department of Justice, "Backgrounder: Stephen Truscott Wrongful Conviction Application", online http://www.justice.gc.ca/eng/news-nouv/nr-cp/2004/doc 31272.html 
Appeal of Ontario which found that a miscarriage of justice had occurred, ${ }^{104}$ the provincial Attorney General appointed a retired judge to advise him on compensation for Mr. Truscott. ${ }^{105}$ Similarly, after the Bernardo trial and a very controversial plea bargain made by the Crown in that case, the Attorney General of Ontario appointed a sitting judge to review the prosecution of the case. ${ }^{106}$

Turning to broader policy reviews, Ontario tapped former Chief Justice Patrick LeSage to conduct a review and make recommendations regarding civilian oversight of the police and then several years later returned to Justice LeSage and asked him to undertake a similar task with regard to long criminal trials. ${ }^{107}$ On the civil side, Justice Coulter Osborne conducted a Civil Justice Review for the Ontario Government ${ }^{108}$ while former Chief Justice McMurtry was kept busy conducting reviews of victim compensation ${ }^{109}$ and youth justice. ${ }^{110}$

In most cases, the judges involved in these and other administrative functions worked diligently to produce first-class work of great value to the development of public policy or the better understanding of a particular issue or event. In such cases, no damage is done to judicial independence, even if the government can be said to have appropriated the virtue of judicial independence for a particular policy exercise. However, when things do go wrong, there is potential for judicial independence to be degraded as a result. Two such examples are discussed in the next section.

${ }^{104}$ See R. v. Truscott, 2007 ONCA 575, [2007] O.J. No. 3221.

${ }^{105}$ In August 2007, the Attorney General of Ontario appointed the Hon. Sydney Robins to advise him on the issue of compensation for Mr. Truscott. See the Hon. Sydney L. Robins, Q.C., In the Matter of Stephen Truscott: Advisory Opinion on the Issue of Compensation (2008), http:/www.attorneygeneral.jus.gov.on.ca/english/about/pubs/truscott/robins report.pdf. See also Tracey Tyler, "Court acquits Truscott" The Toronto Star (28 August 2007). The Government of Ontario accepted Judge Robins recommendations and awarded Mr. Truscott $\$ 6.5$ million. See Robert Benzie, "Truscott's legal nightmare ends" The Toronto Star (8 July 2008).

${ }^{106}$ See A. Campbell, The Bernardo Investigation Review: Report of Justice Archie Campbell (Toronto: The Review, 1996) described by Justice Archie Campbell, "The Bernardo Investigation Review" in Allan Manson \& David Mullan, Commission of Inquiry: Praise or Reappraise (Toronto: Irwin Law, 2003) 381.

${ }^{107}$ See The Hon. Patrick J. LeSage, Q.C., Report on the Police Complaints System in Ontario (Toronto: Ministry of the Attorney General, 2005), online: http://www.attorneygeneral.jus.gov.on.ca/english/about/pubs/LeSage/ and

The Hon. Patrick J. LeSage, CM, Q.C. \& Professor Michael Code, Report of the Review of Large and Complex Criminal Case Procedures (Toronto: Ministry of the Attorney General, 2008), online: http://www.attorneygeneral.jus.gov.on.ca/english/about/pubs/lesage_code/lesage_code_report_en.pdf.

108 The Hon. Coulter A.A. Osborne, Q.C., Civil Justice Reform Project: Summary of Findings \& Recommendations (November 2007), online: http://www.attorneygeneral.jus.gov.on.ca/english/about/pubs/cjrp/.

109 The Hon. R. Roy McMurtry, O. Ont., Q.C., Report on Financial Assistance for Victims of Violent Crime (Toronto: Ontario Ministry of the Attorney General, 2008), online: http://www.attorneygeneral.jus.gov.on.ca/english/about/pubs/mcmurtry/.

${ }^{110}$ See the Hon. R. Roy McMurtry \& Dr. Alvin Curling, Report of the Review of the Roots of Youth Violence (2008), online: $\underline{\text { http://www.rootsofyouthviolence.on.ca/english/reports.asp }}$ 


\section{CAUTIONARY TALES FROM THE USE OF JUDICIAL INDEPENDENCE For Public Policy Purposes}

In the previous section, I discussed some general reasons for the use of judges outside their traditional adjudicative role and some of the problems that may arise in this context. In this section, I use two case studies, one involving a public inquiry and one involving another type of extra-judicial function, to demonstrate how judicial independence can be damaged through such extra-judicial activities.

\section{A. THE SPONSORSHIP INQUIRY}

While only several years old, the Sponsorship Inquiry headed by Quebec Superior Court Justice John Gomery has quickly become a textbook case study in how a judge should not run a public inquiry. More interesting than Judge Gomery's personal actions however, is the question whether the Gomery Inquiry represents an example of a public policy area in which judges should not tread at all. The Sponsorship Scandal was not qualitatively or quantitatively different from other political scandals that have beset Canadian governments - Liberal and Conservative over the past decades. It was triggered by the report of the Auditor General of Canada into the misuse of government funds for advertising on sponsorship activities in Quebec after the near death experience of the Quebec Referendum of 1995. In the face of scandals of a certain magnitude it becomes routine for the opposition to call for "a full public inquiry" into the scandal. Liberal Prime Minister Jean Chrétien successfully avoided such attacks on a number of files: Shawiniganate, Air India and the Human Resources Development Corporation (HRDC) (aka "the Billion Dollar Boondoogle"). The decision to call a public inquiry into the sponsorship scandal was a conscious political choice made by a new Prime Minister, Paul Martin, eager to distinguish his administration from the politics of his predecessor. Ultimately, the public inquiry contributed to the fall of Martin's Liberal government in January 2006 and the return to power of the Conservatives led by Stephen Harper.

The decision to call a public inquiry into the Sponsorship Scandal was a transparent attempt by a new government to use the trappings of judicial office in the attempt to cleanse the taint of political scandal. This decision is widely acknowledged to have been a political miscalculation of monumental proportions. ${ }^{11}$ Not only was the Gomery Inquiry a political

\footnotetext{
111 See e.g. Chantal Hébert, French Kiss: Stephen Harper's Blind Date with Quebec (Toronto: Vintage Canada, 2007) 28-30; Ruth Hubbard \& Gilles Paquet, Gomery's Blinders and Canadian Federalism (Ottawa: University of Ottawa Press, 2007) 7-8; Paul Wells, Right Side Up: The Fall of Paul Martin and the Rise of Stephen Harper's New Conservatism (Toronto: Douglas \& Gibson, 2006) 95-102; 259-62; Eddie Goldenberg, The Way it Works: Inside Ottawa (Toronto: McClelland \& Stewart, 2006) 240.
} 
failure, it was a judicial failure as well. ${ }^{112}$ Its most memorable legacies are tawdry but entertaining political theatre; even the serious policy issues appended to the inquiry's mandate could not elevate the inquiry from the political street. The Gomery Inquiry ended with the ignominious result of a finding that Justice Gomery was biased against former Prime Minister Jean Chrétien and the conclusions relating to Mr. Chrétien were voided. ${ }^{113}$ Ultimately, the actions of Commissioner Gomery tarnished the reputation of the inquiry, of himself and possibly of the Canadian judiciary. In short, the Gomery Inquiry chipped away at the political capital of judicial independence. This came about through a series of actions by Judge Gomery which displayed a serious lack of judgment, the essential judicial quality.

Justice Gomery began the inquiry with a strategic error in hiring Bernard Roy as his Chief Commission Counsel. Mr. Roy is a respected lawyer who had served as Chief Commission Counsel to another commission and was eminently qualified for the job but his appointment was problematic for two reasons. To be clear, both reasons raised problems relating to the appearance of impartiality rather than any questions as to the actual impartiality of Mr. Roy or of Judge Gomery. First, as the former Chief of Staff to Conservative Prime Minister Brian Mulroney, Mr. Roy in his role as Chief Commission Counsel would be targeting former Liberal Prime Minister Jean Chrétien, his former boss's political nemesis. This appointment increased rather than lessened the politicization of the inquiry. ${ }^{114}$ Second, Mr. Roy was a partner in the same law firm as Justice Gomery's daughter which created an appearance that a member of Justice Gomery's family was indirectly benefiting from his appointment. In a less politicallycharged inquiry, it is unlikely that this would have mattered much. However, in this inquiry, it further exacerbated a highly-charged political climate, even more so when Justice Gomery's daughter became the subject of evidence before the inquiry by Prime Minister Chrétien in the attempt to embarrass Justice Gomery.

Next, Judge Gomery made a serious error in giving media interviews during the course of the inquiry in advance of the testimony of Prime Minister Jean Chrétien and other witnesses. This action demonstrated a lack of judgment and ultimately led the Federal Court to declare that it served as the basis for a reasonable apprehension of bias against Mr. Chrétien. ${ }^{115}$ It was Judge Gomery's most critical and most enduring misstep. In the course of the interview, the Judge descended into the ring and engaged in combat with one of the key persons under investigation

\footnotetext{
${ }^{112}$ Cf. Hubbard \& Paquet, ibid. at 8-9 ("Gomery was led to mount a seriously flawed inquiry-thrust as he was into the overheated situation of a daily soap opera fraught with political gamesmanship without clear rules of evidence to assist him in sifting through conflicting testimony and with an insufficient understanding of the complex apparatus of government decision making.").

${ }^{113}$ See Chrétien v. Canada, supra note 84; see Juliet O’Neill \& Janice Tibbetts, "Chrétien bias found in Gomery hearings" National Post (27 June 2008).

${ }^{114}$ See Hubbard \& Paquet, supra note 111 at 42 (stating that Judge Gomery chose his mandate in political terms as evidenced by the appointment of Mr. Roy as his Chief Commission Counsel).

${ }^{115}$ See Chrétien v. Canada, supra note 84. See also James Cowan, "Judge fell for 'spotlight'; 'Detrimental Impact'; Gomery became preoccupied with the media, court finds" National Post (27 June 2008); and Christin Schmitz, "Federal Court admonishes Gomery for "preoccupation with the media"” The Lawyers Weekly (11 July 2008) 1.
} 
who had yet to testify. ${ }^{116}$ In so doing, the Judge appeared more like a participant than an independent arbiter. Not surprisingly, given his storied reputation as a fighter, Mr. Chrétien saved his response for his public and dramatic inquiry testimony in which it is widely acknowledged that he got the best of Judge Gomery, further converting the inquiry into political theatre rather than a serious policy endeavour. To be fair to Judge Gomery, he was taking on the role of inquisitor that he had been asked to assume in this inquiry which was a departure from the ideal type of the neutral judge. His conduct of the inquiry as inquisitor demonstrates the potential problems when we ask judges to move from arbitrators of disputes to inquisitors conducting public inquiries.

Third, Judge Gomery allowed or encouraged his Director of Communications to write a book about the internal workings of the inquiry, aptly titled Inside Gomery. ${ }^{117}$ Judge Gomery wrote the forward in which he attested to the veracity of the book's contents ${ }^{118}$ which were critical of the parties and of commission counsel at times. The book itself was introduced as evidence of Judge Gomery's bias in applications for judicial review of his Commission Report. ${ }^{119}$ Inside Gomery is an interesting account of the process but it makes the inquiry look more like a political soap opera than a serious policy endeavour. It further exposes the chasm between the judicial role and the non-judicial nature of public inquiries; it would be considered beyond a breach of protocol or a lapse of judgment for a judge to permit let alone endorse the publication that revealed the inner workings of a particular judicial proceeding.

Fourth, Justice Gomery became an advocate for his report after it was completed. Justice Gomery spoke out publicly when he felt that the Harper Government (which had inherited the inquiry from its predecessor) was dragging its heals on the implementation of his recommendations. ${ }^{120} \mathrm{He}$ testified before a parliamentary committee on issues relating to his report. $^{121}$ In the past, other commissioners had become advocates for the implementation of their reports, but not in recent history; some judges have clearly stated that commissioners

\footnotetext{
${ }^{116}$ In a series of media interviews in December 2004 prior to the testimony of former Prime Minister Chrétien, Judge Gomery remarked on one aspect of the sponsorship program: golf balls bearing the Prime Minister's signature. Judge Gomery stated: "It's such a disappointment that the Prime Minister would put his name on golf balls. That's really small-town cheap, you know, free golf balls." See Chrétien v. Canada, ibid. at para. 93. The Federal Court found that this was "the most striking evidence" of the lack of Judge Gomery's impartiality towards Mr. Chrétien. Ibid.

${ }^{117}$ See François Perrault, Inside Gomery, trans. Carl Angers (Toronto \& Vancouver: Douglas \& McIntryre, 2006).

${ }^{118}$ John H. Gomery, "Foreword" in ibid. at 3.

${ }^{119}$ See Chrétien v. Canada, supra note 84.

${ }^{120}$ See Jim Brown, "Gomery: 'Where are reforms? Retired judge hammers Harper for ignoring sponsorship reform proposals" The Star.com (30 January 2008); and Daniel Leblanc, "Tories fail to end era of secrecy, Gomery says" The Globe and Mail (14 March 2008)

${ }^{121}$ See Richard Brennan, "PMO's power threatens democracy, Gomery says" The Toronto Star (13 March 2008) ("The growing power among unelected personnel in the Prime Minister's Office is a threat to democracy, retired Justice John Gomery says”). Jim Brown, “Gomery criticizes PMO's hold on power” The Star (31 January 2008).
} 
should not adopt an advocate's role respecting their reports. ${ }^{122}$ While by this time Judge Gomery had retired from the bench and was back to being "an ordinary citizen", the difficulty was that Justice Gomery's actions compounded an already problematic situation. Moreover, Judge Gomery continued to attack the Harper government, criticizing the Prime Minister for delaying in calling a public inquiry into the Mulroney-Schreiber affair. ${ }^{123}$

\section{B. The Chief Justice, Abortion, And the Order of CAnada}

Outside of public inquiries, there are other extra-judicial functions that governments assign to judges in the attempt to cloak political decisions with an aura of independence removed from the taint of the politics. The apolitical façade usually holds but at times it breaks down and when it does, the political nature of such decisions is readily apparent. The involvement of the Chief Justice of Canada in the selection of members for the Order of Canada, Canada's highest honour, is a case in point.

The purpose of the Order of Canada is to recognize Canadians for their outstanding contributions to their communities, to Canada and to humanity. There are three levels in the Order of Canada: members, officers and companions. The qualifications for induction to the Order of Canada are "distinguished service in or to a particular community, group or field of activity" (member); "achievement and merit of a high degree, especially service to Canada or to humanity at large" (officer); and outstanding achievement and merit of the highest degree, especially in service to Canada or to humanity at large" (companion, the highest level within the Order). ${ }^{124}$ These criteria are inherently subjective and no further formal guidelines exist to guide the decision making process. The selection of members involves an exercise of political judgment in terms of making decisions as to which type of activities in which fields warrant recognition. There is also a sensitivity to the national character of the Order; each announcement of new members of the Order includes persons from all across Canada. More troubling for its legitimacy, the Order of Canada has been criticized for "political correctness"125 or "leftist leanings". ${ }^{26}$ Such accusations have been dismissed by the leading scholar on the Order, ${ }^{127}$ but

\footnotetext{
${ }^{122}$ See e.g. O'Connor \& Kristjanson, supra note 5; Willard Estey, "The Use and Abuse of Inquiries: DO They Serve a Policy Purpose?" in A. Paul Pross, Innis Christie \& John A. Yogis, Commissions of Inquiry (Toronto: Carswell, 1990) 209 at 215.

123 "Mulroney-Schreiber inquiry should begin, Gomery says" The Globe and Mail (29 May 2008); Jim Brown, "Gomery chides Harper for delay in Mulroney-Schreiber inquiry" The Globe and Mail (28 May 2008).

124 Constitution of the Order of Canada, ss. 11 (companion), 16 (officer), 18 (member), online: http://www.gg.ca/honours/nat-ord/oc/oc-con_e.asp.

${ }^{125}$ See e.g. Henry Aubin, "We need the Order, but not the political correctness that goes with it", The Montreal Gazette (15 July 2008).

${ }^{126}$ James Cowan, "Leftist Leanings: Order carries history of rebukes” The National Post (2 July 2008).
} 
the composition of the Advisory Council on the Order may explain why persons from the arts, academia and government are favoured recipients of the Order. The persons who recommend candidates to receive the Order are the Clerk of the Privy Council (the top federal Civil Servant in Canada); the Deputy Minister of the Department of Canadian Heritage; the Chairperson of the Canada Council; the President of the Royal Society of Canada; the Chairperson of the Board of Directors of the Association of Universities and Colleges of Canada; and five members of the Order appointed on the recommendation of the other members of the Advisory Council. The Chief Justice of Canada chairs the Advisory Committee. ${ }^{128}$

It is not readily apparent why the Chief Justice of Canada - or any judge - should be a part of, let alone chair, this body. It is not a judicial body. Certainly, the Chief Justice of the Supreme Court is a national figure and we would expect such person to be well-versed in national affairs and well-placed to exercise judgment on the contributions of worthy Canadians to our society. But that is inherently a political decision, not a judicial one. ${ }^{129}$

The decisions regarding the Order are inherently political - not in the sense of being partisan ${ }^{130}$-- but in the sense of being an exercise of discretion that reflects a judgment about the relative value of the contributions of various individuals to Canadian society. ${ }^{131}$ To give a recent and high-profile example, in 2008 the Advisory Committee recommended long-time abortion activist Dr. Henry Morgentaler for the Order of Canada. The controversial nature of this appointment ripped away the usual non-political façade that surrounds the Order. ${ }^{132}$ In the 1970s and 1980 s as Dr. Morgentaler was challenging the Criminal Code of Canada's restrictions on abortion in the courts, a pro-life crusader named Joseph Borowski was also challenging them as insufficiently protective of the rights of the unborn foetus. ${ }^{133}$ In awarding the Order of Canada to

${ }^{127}$ See ibid. Cf. Christopher McCreery, The Order of Canada: Its Origins, History and Developments (Toronto: University of Toronto Press, 2005).

${ }^{128}$ Constitution of the Order of Canada, s. 7, online: http://www.gg.ca/honours/nat-ord/oc/oc-con_e.asp.

${ }^{129}$ Chief Justice McLachlin explained that as the Chair she does not vote but rather ensures that the meetings are conducted in an orderly fashion. However, as there are no minutes of the Advisory Council meetings that are released to the public, the decisions of the Advisory Council are treated as collective recommendations. Moreover, it is clear that when the Order of Canada Advisory Council was set up the Chief Justice was intended to have a vote and did exercise that vote. See McCreery, supra note 137 at 137-38 (describing the workings of the first Advisory Council, chaired by Chief Justice Robert Taschereau).

${ }^{130}$ For example by convention all former Prime Ministers are appointed Companions of the Order of Canada - the highest rank within the Order of Canada. Notably all Supreme Court Justices are made Companions of the Order after they retire. However, provincial premiers, retiring MPs or federal Cabinet Ministers do not automatically or ordinarily receive investitures in the Order. This is but one example of the political judgment exercised by the Advisory Committee in deciding what types of public service is meritorious.

${ }^{131}$ Cf. Black v. Chrétien (2001), 54 O.R. (3d) 215 at paras. 62-63 (holding that the conferral of an honour involves a moral and political considerations which are not justiciable in the courts).

${ }^{132}$ See e.g. Caroline Alphonso \& Bill Curry, "Cheers, jeers greet abortions crusader's honour; PMO distances itself from Morgentaler's appointment" The Globe and Mail (2 July 2008) A1.

${ }^{133}$ See Borowski v Canada (Attorney General) 29 Sask. R. 16, 4 D.L.R. (4th) 112, [1984] 1 W.W.R. 15, 8 C.C.C. (3d) 392, 36 C.R. (3d) 259, aff'd (1987), 56 Sask. R. 129, 39 D.L.R. (4th) 731, [1987] 4 W.W.R. 385, 33 C.C.C. (3d) 402, 59 
Dr. Morgentaler but not to Mr. Borowski or a similarly high profile pro-life activist, ${ }^{134}$ the Advisory Committee chaired by the Chief Justice of Canada may be perceived as taking sides in one of the most divisive social debates in Canada. ${ }^{135}$ The political nature of the appointment was apparent in politicians' responses, with Liberal leader Stéphane Dion claiming, in a phrase more akin to the politician's standard responses to judicial decisions, that politics should be kept out of the Order of Canada process and calling on Canadians to "respect and celebrate" the decisions of the panel and the Governor General. ${ }^{136}$ The Conservative Government's strategy was to distance itself from the Order of Canada appointment process and the Government issued talking points along such lines. In fact, Government statements specifically noted that the selection of the Order of Canada was an independent process and explicitly mentioned that the Chief Justice chaired the Advisory Committee. ${ }^{137}$ That is, the Government was able to distance itself from the selection of Dr. Morgentaler by invoking the independence of the Chief Justice of Canada. Consequently, the Advisory Committee and the Chief Justice in particular, were thrust into the

C.R. (3d) 223, appeal dismissed as moot [1989] 1 S.C.R. 342. See generally F.L. Morton, Morgentaler versus Borowski: Abortion, the Charter, and the Courts (Toronto: McClelland \& Stewart, 1993).

${ }^{134}$ Such as Dr. Margaret Somerville, founding Director of the Centre for Medicine, Ethics and Law at McGill University as some have suggested. See Norma Greenway, Canwest News Service, "Order of Canada award decided in secret" Canwest News Service (2 July 2008), online: http://www.canada.com/topics/news/national/story.html?id=75e4dc61-7312-4914-a5d6-bf4b9e19a6e0

${ }^{135}$ Dr. Morgentaler has been a leading figure in Canadian law and public policy for three decades. His Order of Canada citation provides: "Henry Morgentaler has had a major impact on Canadian public policy. A Holocaust survivor, he has not hesitated to put himself at risk in his determined drive to increase health care options for Canadian women. He has been a catalyst for change and important debate, influencing public policy nationwide. He has heightened awareness of women's reproductive health issues among medical professionals and the Canadian public. He is a respected volunteer who has held leadership roles in humanist and civil liberties organizations, and is the recipient of a number of national and international awards." Online: http:/www.gg.ca/media/doc.asp?lang=e\&DocID=5514. However, some of the responses to the announcement of Dr. Morgentaler's appointment to the Order of Canada demonstrate the strength of feelings about his appointment. Joanne Byfield, president of Life Canada as saying "I understand people love Henry Morgentaler . . . but to make this an official Canadian position, which is to say we Canadians think this man is a hero because he kills babies for a living, is outrageous.”. Canadian Auto Workers Union president Buzz Hargove, named to the Order the same day as Dr. Morgentaler said "I'm absolutely thrilled to be on the list at the same time as Dr. Morgentaler. I supported him. I supported his efforts. I think he's done more for half the population in this country . . in terms of fighting for women's reproductive rights". Thomas Collins, the Roman Catholic Archbishop of Toronto said in a statement that the inclusion of Dr. Morgentaler in the Order of Canada "debased" the country's highest honour and that Dr. Morgentaler had brought "the destruction of the defenseless and immeasurable grief." See Alphonso \& Curry, ibid. at A1, A10. See also Angelo Persichili, "Don't Honour Morgentaler - at least not now" The Toronto Sun (6 July 2008) (stating that the decision sends the wrong message about respect for the law).

\footnotetext{
${ }^{136}$ Alphonso \& Curry, ibid. at A10.
}

${ }^{137}$ However, veteran maverick Conservative MP Art Hanger refused to follow that script, opining that "it's a sorry day when they give that man the Order of Canada" and regretting that Canada lacked a law to protect "the taking of the life of the unborn." Alphonso \& Curry, ibid. 
centre of the firestorm of controversy, potentially undermining judicial independence in the process. $^{138}$

The potential harm to judicial independence was raised in some of the responses to the announcement of Dr. Morgentaler's appointment. Some accused the Chief Justice of taking sides in the abortion debate and questioning whether she could be impartial in adjudicating future abortion-related cases. A coalition of pro-life groups launched a complaint against the Chief Justice with the Canadian Judicial Council. ${ }^{139}$ The Chief Justice of Canada responded by taking the highly unusual step of publicly rejecting the accusations of bias and defending her role in the Order of Canada process. The Chief Justice explained her role as follows: "I'm there to make sure the meeting runs well and fairly and that the vote is taken fairly - and not to weigh in for, or against, any particular candidate". ${ }^{140}$ If this is the case, it further demonstrates the lack of connection between her role as chair and any judicial expertise. Her role then has no operational significance, but has great symbolic and political value. The participation of the Chief Justice may help enhance the perception of the non-political and independent nature of the Order of Canada but at a cost to judicial independence. At the same time and venue as the Chief Justice of Canada was explaining her role in the Order of Canada, the Chief Justice of Manitoba opined that some extrajudicial functions may undermine the judicial role and that perhaps judges should reconsider the advisability of acting in such capacities. ${ }^{141}$ To be clear, the Chief Justice of Canada has no such option regarding the Order of Canada. She is required to Chair the Advisory Council under the Constitution of the Order. ${ }^{142}$ It would require a change to that constitution to free the Chief Justice of this responsibility. And it should be so amended. ${ }^{143}$

It is not clear what is functionally gained in having the Chief Justice of Canada chair the advisory committee beyond strengthening the non-partisan nature of the award and attempting to create the appearance that the process is a non-political one. However, as the Morgentaler

\footnotetext{
${ }^{138}$ Similarly, judges sit on the federally-appointed Judicial Advisory Committees (JACs) that advise the Minister of Justice on judicial appointments. As Jacob Ziegel argues in his contribution to this book, some of those appointments may be based on political considerations.

139 See Tracey Tyler, "Top judge rejects bias charge; Beverley McLachlin defends role in process that gave Morgentaler Order of Canada" The Toronto Star (17 August 2008).

${ }^{140}$ Ibid. The complaint against the Chief Justice was ultimately dismissed. See Linda Nguyen, "Complaint against Canada's chief justice dismissed" Canwest News Service (25 September 2008).

${ }^{141}$ See Janice Tibbetts, "Think twice about heading public inquiries, judges told", Canwest News Service (17 August 2008), online: http://www.canada.com/story.html?id=730728

${ }^{142}$ The Chief Justice of Canada at the time, Chief Justice Robert Taschereau, was involved in the creation of the Advisory Committee and agreed to Chair it. See McCreery, supra note 127 at 117-18, 127-28. Indeed, as Governor General Vanier died on March 5, 1967, it was Chief Justice Taschereau as the acting Governor General who made the submission to the Queen seeking her formal approval for the creation of the Order. Ibid. at 128.

${ }^{143}$ The Constitution of the Order of Canada is established by Order-in-Council and could thereby be changed by Order-in-Council, i.e. by a decision of the federal Cabinet. For example, in 2001, the Constitution of the Order of Canada was amended by Order-in-Council to change the composition of the Advisory Council. See P.C. 2001-303 March 1, 2001.
} 
episode demonstrates, there is a risk that the involvement of the Chief Justice in this process can undermine judicial independence.

\section{THE LONG TERM IMPACT}

The Gomery Inquiry and the Chief Justice's involvement in the awarding of the Order of Canada to Dr. Henry Morgentaler are only two of a larger group of recent examples of judicial activity outside of the courtroom that threatens to damage the valuable societal good of judicial independence. Other examples include the October 2008 resignation of Justice Harry LaForme, Canada's highest serving Aboriginal judge, as Chair of the Truth and Reconciliation Commission into Indian Residential Schools because he feared outside rather than governmental interference with his independence ${ }^{144}$ and the decision by Ontario's Attorney General that same week to shut down the Cornwall Inquiry after three years and $\$ 37$ million. ${ }^{145}$

The potential harms to judicial independence are both individual and institutional. It has long been recognized that the judge who takes on extra-judicial functions risks having his or her impartiality questioned should an issue related to the subject matter of their non-judicial activity arise before them in Court. ${ }^{146}$ In certain cases, it is difficult to see how a particular judge who had written a report and made certain factual findings and advocated a particular policy position could be reasonably perceived by the public as an impartial adjudicator on a related matter. In the circumstances of the Chief Justice's involvement in the awarding of the Order of Canada to Dr. Morgentaler, concerns were raised regarding the Chief Justice's impartiality on future related issues before the Supreme Court of Canada. ${ }^{147}$ If a judge continues to advocate for recommendations made extra-judicially, this may further call into question the judge's impartiality at least in respect to this issue should it arise judicially.

Institutionally, attacks on an individual judge's impartiality may taint the entire court, particularly if it is a court of appeal or the Supreme Court of Canada. In the limited experience in this area, allegations of bias against an individual Supreme Court justice have attempted to taint the entire Court. ${ }^{148}$ Extra-judicial activities by judges increase the risk of allegations of bias

\footnotetext{
${ }^{144}$ See Joe Friesen, “Judicial Independence key to LaForme's resignation” Globe and Mail (24 October 2008) A4.

${ }^{145}$ Canadian Press, "Ont. orders inquiry into sex abuse allegations in Cornwall to wrap up by July" (23 Oct. 2008), online: http://canadianpress.google.com/article/ALeqM5iH9vTc9RPMqMENt4pRA0XLFmI5Kw. The Attorney General announced that Cabinet had issued an Order-in-Council instructing the Cornwall Inquiry to conclude hearings by the end of January 2009 and deliver its report to him by July.

${ }^{146}$ See e.g. Canadian Bar Association, supra note 78 at 43.

${ }^{147}$ Tracey Tyler, "Top judge rejects bias charge; Beverley McLachlin defends role in process that gave Morgentaler Order of Canada" The Toronto Star (17 August 2008).

${ }^{148}$ See Wewaykum Indian Band v. Canada, [2003] S.C.J. No. 50, [2003] 2 S.C.R. 259, 2003 SCC 50, denying motion to vacate [2002] S.C.J. No. 79, [2002] 4 S.C.R. 245, 2002 SCC 79 (motion to vacate judgment on the basis of allegations bias against Binnie J. which allegedly tainted judgment of entire Court). This was a highly unusual
} 
against them and against the Court upon which they sit. Thus, it is likely that should a case involving Dr. Morgentaler or one of his clinics come before the Court, one of the parties will bring a motion to disqualify the Chief Justice based on her involvement in awarding the Order of Canada to him. This would be an unnecessary questioning of the Chief Justice and the Court's impartiality which has the potential to undermine the Court's legitimacy as an impartial arbiter of disputes.

\section{CONCLUSION: WHEN TO SAY YeS AND LEARNING TO SAY NO - The Future for Judicial Independence as Public Policy ToOL}

In this paper, I have described the growing trend in Canada towards the judicialization of politics through the Executive's use of judges to assume various public policy roles. In many cases, the motives of the Executive cannot be impugned and involve the desire to address a particular public policy problem. However, in some cases what the executive is seeking is not the expertise of a particular judge (although in some cases they certainly are) but rather a generic judge accompanied by the substantial political capital of judicial independence. As I outlined in Part II of this paper, the concept of judicial independence is directly tied to the adjudication of disputes. Judicial independence is a second-order norm, valued not in and of itself, but rather as a means of promoting and ensuring first-order norms such as impartiality and the rule of law. When judges engage in extra-judicial activities, by definition they are acting outside of their core judicial role in adjudicating disputes. As I have attempted to demonstrate in this paper, this creates something of a paradox. The rationale for judicial independence disappears when judges are acting outside of their judicial role but it is precisely this independence that the executive branch of government is tapping into and drawing upon as a political capital to assist the executive in dealing with various public policy issues.

While there is no question that the use of judges in various extra-judicial capacities has significant public policy benefits, it may also have negative implications. ${ }^{149}$ In this paper, I have focused on one such negative effect: the potential damage to judicial independence over the long term through the over-reliance on its appropriation by the executive with the acquiescence of the

case. See generally Adam M. Dodek, "Constitutional Legitimacy and Responsibility: Allegations of Bias after Wewaykum Indian Band v. Canada" (2004), 24 SCLR (2d) 165. The normal procedure is to bring a motion to recuse a particular judge, before that judge. See e.g. Arsenault-Cameron v. Prince Edward Island, [1999] S.C.J. No. 75, [1999] 3 S.C.R. 851 (Bastarache J.).

${ }^{149}$ In this paper I have not addressed what I see as the weakening of other branches of government, especially the legislature, through the routine reliance on judges to conduct public inquiries and other public policy functions. We have moved from a culture that values independence to one characterized by a cult of independence where governments are unwilling or unable to address serious public policy issues without outsourcing this responsibility to "independent" outside experts. This does not bode well for the long term health of our democratic institutions. 
judiciary. As my colleagues Ed Ratushny and Daphne Gilbert have recently argued, "[t]he independence and impartiality of the Canadian judiciary is a national treasure. No risk should be taken of placing it in jeopardy, no matter how remote that risk might be."150 For these reasons, we need to ensure that judicial independence is not compromised by extra-judicial activities. Below I outline how I think this issue should be addressed in Canada.

The default rule that judges are always available to take up executive tasks should be changed. In light of tradition and practice in Canada, I do not think it wise that we go the route of Australia or the United States and essentially prohibit most extra-judicial executive activities by judges. However, I do think that the judiciary needs to become more selective and more assertive in deciding which functions that they should take on. This needs to be done both on a categorical level with respect to what sorts of extra-judicial activities are proper or prudent as well as on a case by case basis when issues arise. There needs to be both a process and principles to evaluate extra-judicial activities.

First, as far as process there needs to be both judicial reflection on these issues as well as discussion with the executive. On the former, Chief Justices, judges associations and the Canadian Judicial Council should begin to think about ways to address the issue of the appropriateness of taking on extra-judicial roles. As the body statutorily-charged with overseeing the conduct of federally-appointed judges, the Canadian Judicial Council is uniquely placed to take a leadership role on this issue. It has already taken strides in this respect with its 1998 statement on the appointment of federally-appointed judges to commissions of inquiry and its cautions in the Ethical Principles for Judges. It should build on this work by striking a committee or working group to determine guidelines for what sorts of activities federallyappointed judges should and should not carry out that would revisit, expand and operationalize its 1998 work. The Canadian Judicial Council should also establish a committee that would vet all requests for a federally-appointed judge to head a public inquiry, assume a proposed new legislated role, or take on an ad-hoc executive assignment. A general request would be made first to this committee and then to the Chief Justice of the court in which the proposed judge sits. The Chief Justice of that court ultimately retains veto power but any decision would be made in consultation with the committee of the Canadian Judicial Council. To be clear, I think that Chief Justices have not been exercising their veto power as often as they should and that an established committee of the Canadian Judicial Council which does not work with a provincial or federal government on a daily basis - as Chief Justices and their offices do - may be better positioned to provide advice on the pitfalls of some proposed extra-judicial activity. It would also be easier for a Chief Justice to say no when the Canadian Judicial Council is part of the equation.

Once the judiciary as an institution have begun to consider the ramifications of extrajudicial activities, they should engage the executive at both the federal and provincial levels in order to establish both substantive guidelines as to what sort of executive activities are

\footnotetext{
${ }^{150}$ Ed Ratushny \& Daphne Gilbert, "The Lamer Legacy for Judicial Independence" in Adam Dodek \& Daniel Jutras, The Sacred Fire: The Legacy of Chief Justice Antonio Lamer / Le feu sacré: l'héritage d'Antonio Lamer, juge en chef du Canada (Toronto: LexisNexis, 2009).
} 
appropriate for judges to take on as well as procedural guidelines for determining the appropriateness of a particular request by the Executive.

As far as the substantive principles that should be considered in both processes, again, the Canadian Judicial Council's 1998 work provides an excellent foundation. The key factors set out in the 1998 statement remain the touchstones for consideration. First and foremost, judges should not involve themselves in disputes that are essentially of a partisan nature. Second, they should not be used to conduct investigations which essentially involve criminal or civil liability. Third, the executive must give judges sufficient institutional support in terms of resources, time and independence in order to be able to successfully complete their mandate. Fourth, is the proposed extra-judicial activity essentially an attempt to relitigate an issue that the executive chose not to pursue in the courts. Fifth, in each case, the judiciary as an institution must inquire as to why a judge or a specific judge is required for the desired action, as opposed to a lawyer or another person. In every instance, consideration of each particular public inquiry or extrajudicial executive assignment requires a consideration of principle and pragmatism.

Despite their contribution to public policy development, individual judges and particularly chief justices should begin to exercise more discretion in accepting such appointments. ${ }^{151}$ They should not acquiescence to judicial participation in every political inquiry or other activity that the political executive wishes to launch. Having set out standards for the exercise of discretion, the Canadian Judicial Council needs to take a more active role and chief justices should begin to exercise that discretion. Sometimes, in the name of protecting judicial independence, the judiciary needs to say no to the executive.

\footnotetext{
${ }^{151}$ I have not delved into the motivation for judges accepting such appointments but I believe that in most cases intellectual stimulation, tradition and a sense of duty or public service (qualities which likely attracted such individuals to the bench in the first place) are the overriding motivators. In some cases, ambition or a desire to be in the public limelight may motivate judges to accept such appointments, however I think these are the exception rather than the rule. The problem, in my estimation, is that judges and the judiciary are inclined to accept extra-judicial appointments out of a sense of public duty because "it is the right thing to do". As I have argued here, this is not always the case.
} 